\title{
Current Knowledge on Selenium Biofortification to Improve the 2 Nutraceutical Profile of Food: A Comprehensive Review
}

\author{
3 Roberto D’Amato, Luca Regni, Beatrice Falcinelli, Simona Mattioli, Paolo Benincasa,* \\ ${ }_{4}$ Alessandro Dal Bosco, Pablo Pacheco, Primo Proietti, Elisabetta Troni, Claudio Santi, \\ $s$ and Daniela Businelli
}

Cite This: https://dx.doi.org/10.1021/acs.jafc.0c00172

Read Online

6 ABSTRACT: Selenium (Se) is an important micronutrient for living organisms, since it is involved in several physiological and 7 metabolic processes. Se intake in humans is often low and very seldom excessive, and its bioavailability depends also on its chemical 8 form, with organic Se as the most available after ingestion. The main dietary source of Se for humans is represented by plants, since 9 many species are able to metabolize and accumulate organic Se in edible parts to be consumed directly (leaves, flowers, fruits, seeds, 10 and sprouts) or after processing (oil, wine, etc.). Countless studies have recently investigated the Se biofortification of plants to 11 produce Se-enriched foods and elicit the production of secondary metabolites, which may benefit human health when incorporated 12 into the diet. Moreover, feeding animals Se-rich diets may provide Se-enriched meat. This work reviews the most recent literature on 13 the nutraceutical profile of Se-enriched foods from plant and animal sources.

14 KEYWORDS: speciation, micronutrient, metabolite, vegetable, fruit, meat

\section{INTRODUCTION}

16 Selenium (Se) is an essential micronutrient, and an adequate 17 intake of this essential trace element is thought to be beneficial 18 for maintaining human health. ${ }^{1}$ It is present in several natural 19 kingdoms, humans, animals, cyanobacteria, ${ }^{2}$ and some plants; 20 it contributes to the control of water status of plants, ${ }^{3}$ prevents 21 oxidative stress, delays senescence, and promotes growth. ${ }^{4,5}$

22 More than 25 selenium-containing proteins have been 23 identified in mammals and are distributed in different tissues 24 and cells, ${ }^{6}$ having in all cases a role in the regulation of redox 25 processes. Glutathione peroxidase $(\mathrm{GPx})$ is the most studied 26 and well characterized selenoprotein, and its involvement in 27 the detoxification of reactive oxygen species (ROS) has been 28 clearly demonstrated. Similar activity was reported for 29 thioredoxin reductase ( TrxR) and selenoprotein $\mathrm{P}$, whereas 30 the analogues $\mathrm{K}, \mathrm{M}, \mathrm{N}$, and $\mathrm{H}$ have a number of different roles 31 in the maintenance of the redox homeostasis of living systems, 32 and iodothyronine deiodinases (DIO) have a fundamental role 33 in the activation of the thyroid hormones. ${ }^{7}$ All these proteins 34 have as a common characteristic the presence of a 35 selenocysteine 21 st amino acid in which the catalytic core is 36 a selenol/selenolate stabilized by a amino acidic triad. ${ }^{8}$ 37 Included in the biological processes that can be modulated 38 by Se are not only the cellular response to oxidative stress but 39 also the cellular differentiation, function (including enterocytes 40 and adipocytes), immune response; the redox signaling and 41 protein folding; and the regulation of insulin action and 42 secretion. ${ }^{9}$

43 People living in the United States and Canada normally have 44 no problems connected with Se deficiency; ${ }^{10}$ on the contrary, 45 those who live in China, New Zealand, and parts of Europe and Russia occasionally show an insufficient intake of this 46 micronutrient due to low levels of $\mathrm{Se}$ in soil and, as a 47 consequence, in food. ${ }^{11}$

\section{8}

Se concentration in mammals' serum ranges between 7 and 49 $14 \mu \mathrm{g} / \mathrm{dL},{ }^{12}$ and Se is taken in by food as both inorganic forms 50 (such as selenite, $\mathrm{SeO}_{3}{ }^{2-}$, and selenate, $\mathrm{SeO}_{4}{ }^{2-}$ ) and/or 51 organic derivatives (such as the amino acid selenomethionine 52 (SeMet) and selenocysteine (SeCys)). As for many nutrients, 53 several studies in humans have provided evidence of a U- 54 shaped relationship between Se concentration in the blood and 55 the risk of disease, with possible harm occurring both below 56 and above the physiological range for optimal activity of some 57 or all selenoproteins. ${ }^{13}$ High serum Se levels are associated 58 with increased risk such as in the case of diabetes mellitus, ${ }^{14} 59$ while Se deficiency occurs when the intake is lower than 2060 $\mu \mathrm{g} /$ day, and this condition has been correlated to a number of 61 pathologies including cancers, Alzheimer's or Parkinson's 62 disease, male infertility, and thyroidal dysfunctions. ${ }^{7} \quad 63$

Some plants, in the presence of high levels of inorganic Se, 64 can metabolize and accumulate $\mathrm{Se}$ in the form of organic 65 derivatives. This process is important for the plant because it 66 reduces the toxicity of the chalcogen, and at the same time, 67 when bioaccumulation occurs in edible tissues, this process 68

Received: January 13, 2020

Revised: March 12, 2020

Accepted: March 17, 2020

Published: March 17, 2020 
69 allows the production of Se-enriched foods that have use as a 70 potential nutraceutical for humans and animals. ${ }^{15}$ Moreover, 71 Se biofortification may elicit the production of secondary 72 metabolites, which may benefit human health when assumed 73 with the diet. ${ }^{16-18}$

74 Therefore, biofortification strategies applied to produce Se75 enriched foods could help overcome Se deficiency and its

76 implications in human health and improve the nutraceutical 77 value of food. Despite several scientific works that have dealt 78 with Se-biofortification strategies, the production of Se79 enriched foods suitable for animal and human consumption 80 is still challenging.

81 This review is focused on the Se biofortification of plants to 82 obtain both Se- and phytochemical-enriched foods and feeds, 83 which are potentially useful in increasing, directly or indirectly 84 (i.e., by transfer to livestock meat obtained with Se-enriched 85 feeds), human intake of Se and bioactive compounds. Studies 86 concerning Se content in mushrooms are not included here 87 since the wide literature devoted to this subject would deserve 88 a specific review, taking into account also Se-containing 89 proteins and polysaccharides that are of interest in cancer 90 chemoprevention. ${ }^{19,20}$

91 Since different Se forms have different bioavailability as well 92 as different metabolic pathways, Se speciation analysis is 93 examined first as a powerful tool to evaluate the Se species in 94 the Se-enriched foods.

\section{ADVANCES IN SPECIATION ANALYSIS}

96 Total Se concentration (TSeC) in biofortification is 97 determined to evaluate the biofortification efficiency. However, 98 this information is incomplete considering that different Se 99 species possess different bioavailability for humans. It is well100 known that organic Se forms (e.g., Se amino acids) are more 101 bioavailable than inorganic forms, such as selenite and 102 selenate; indeed, the human body absorbs more than $90 \%$ of 103 SeMet but only about $50 \%$ of Se from selenite. ${ }^{21}$

104 In humans, Se absorption from products of plant origin is 105 much easier than Se absorption from products of animal origin. 106 Therefore, scientists are mostly interested in analyzing Se 107 speciation in plant-derived fortified foods. ${ }^{22}$

108 The analysis of Se species requires considerations from the 109 treatment of samples to the identification and quantification of 110 these species. The selenol group $(-\mathrm{SeH})$ of $\mathrm{SeCys}$ and other 111 Se-amino acids have very low oxidation potential. During 112 extraction procedures, the addition of dithiothreitol (DTT) is 113 advised to avoid oxidation. ${ }^{23}$ Direct analysis of Se species in 114 samples can also be performed by using X-ray absorption near 115 edge structure (XANES) and extended X-ray absorption fine 116 structure (EXAFS). ${ }^{24}$ Similarly, laser ablation (LA) coupled to 117 inductively coupled plasma mass spectrometry (ICP MS) has 118 been used for bioimaging the Se distribution and localization in 119 tissues. $^{25}$

120 The principal analytical approach to Se speciation has been 121 based on the fractionation and separation of extracts by 122 chromatography (or electrophoresis) while specifically mon123 itoring Se by ICP MS. High performance liquid chromatog124 raphy (HPLC) has almost universal applicability, and it is the 125 most versatile separation technique, which benefits from a wide 126 array of stationary phases providing different separation 127 modes. $^{26}$

128 ICP MS can be used for the quantification of Se species, 129 owing to its high sensitivity and element-specific analytical 130 response, independent of the molecular structure, even in case of unidentified Se species. At first sight, it seems there is a full 131 compatibility between HPLC and the traditional sample 132 introduction system of ICP MS, as HPLC provides a typical 133

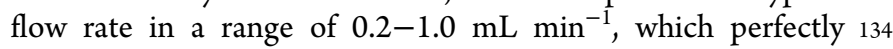
matches the flow rate range of the traditional nebulizers used 135 (in combination with a spray chamber) for sample 136 introduction in ICP MS. Three different ICP MS sample 137 introduction systems (i.e., a micro concentric nebulizer 138 mounted onto a cyclonic spray chamber, a direct injection 139 nebulizer (DIN), and an ultrasonic nebulizer) were compared 140 in the context of HPLC ICP MS analysis of Se species. The 141 micro-concentric nebulizer combined with a cyclonic spray 142 chamber was found to be the optimal sample introduction 143 system, taking the chromatographic peak shape, sensitivity, and 144 limits of detection (LODs) into account. Ar-based spectral 145 interferences, while monitoring the ion signals of the ${ }^{78} \mathrm{Se},{ }^{80} \mathrm{Se}, 146$ and ${ }^{82} \mathrm{Se}$ isotopes, can be solved with methane as a reaction gas 147 in the dynamic reaction cell (DRC) used in ICP MS to 148 eliminate the on-mass. ${ }^{27}$ The quantification accuracy of Se 149 species can be increased by isotopic dilution mass spectrom- 150 etry (IDMS). The principle of IDMS is based on the alteration 151 of the isotopic ratio of the analyte's two or more isotopes, by 152 spiking the sample with an isotopically enriched standard. By 153 applying relevant mathematical equations for IDMS and 154 measuring the altered isotopic ratio, the concentration in the 155 sample can be obtained. IDMS can be performed as a species- 156 specific or a species-unspecific analysis.

The identification of Se metabolites can usually be achieved 158 by using traditional techniques, MS and Nuclear Magnetic 159 Resonance (NMR). Electrospray ionization (ESI) in MS is 160 often used either in tandem with ICP MS or as a 161 complementary detector. ESI is a soft ionization mode that 162 can preserve the molecular form of biomolecules, and since its 163 implementation into analytical methods, this instrument has 164 proven to be invaluable for the structural elucidation of 165 molecular species. On the other hand, ESI MS also enables 166 fragmentation of selected molecules, and produced fragments 167 are very often crucial in the identification of unknown 168 molecular species. The identification of novel Se species has 169 been exclusively done by ESI MS, with high molecular mass 170 precision, when high resolution instruments such as Orbitrap, 171 ESI, time of flight (TOF) MS, or ESI MS/MS are used. ${ }^{25}$ In 172 addition, the growing sensitivity of ICP MS detection, owing to 173 collision cell and triple quadrupole mass spectrometers, has 174 resulted in an increasing number of unidentified peaks in 175 HPLC and ICP MS chromatograms.

176

On the level of selenoproteins, bioinformatics approaches 177 have allowed the putative description of selenoproteomes (sets 178 of Se-containing proteins with genetically introduced seleno- 179 cystein via a SeCys element). In parallel, the increasing 180 robustness of ESI sources and the advent of high-resolution 181 high-mass-accuracy mass analyzers (notably TOF and Orbi- 182 trap) coupled with HPLC continuously increased the number 183 of identified compounds. ${ }^{26}$

SELENIUM BIOFORTIFICATION STRATEGIES IN PLANTS

Agronomic Se biofortification has many advantages over direct 187 Se supplementation, since inorganic Se absorbed by the plant 188 is transformed into organic forms, which have a higher 189 bioavailability. Many variables are involved in Se biofortifica- 190 tion strategies, such as the Se administration mode (soil 191 fertilization, foliar spray, or hydroponics), Se dose, species and 192 


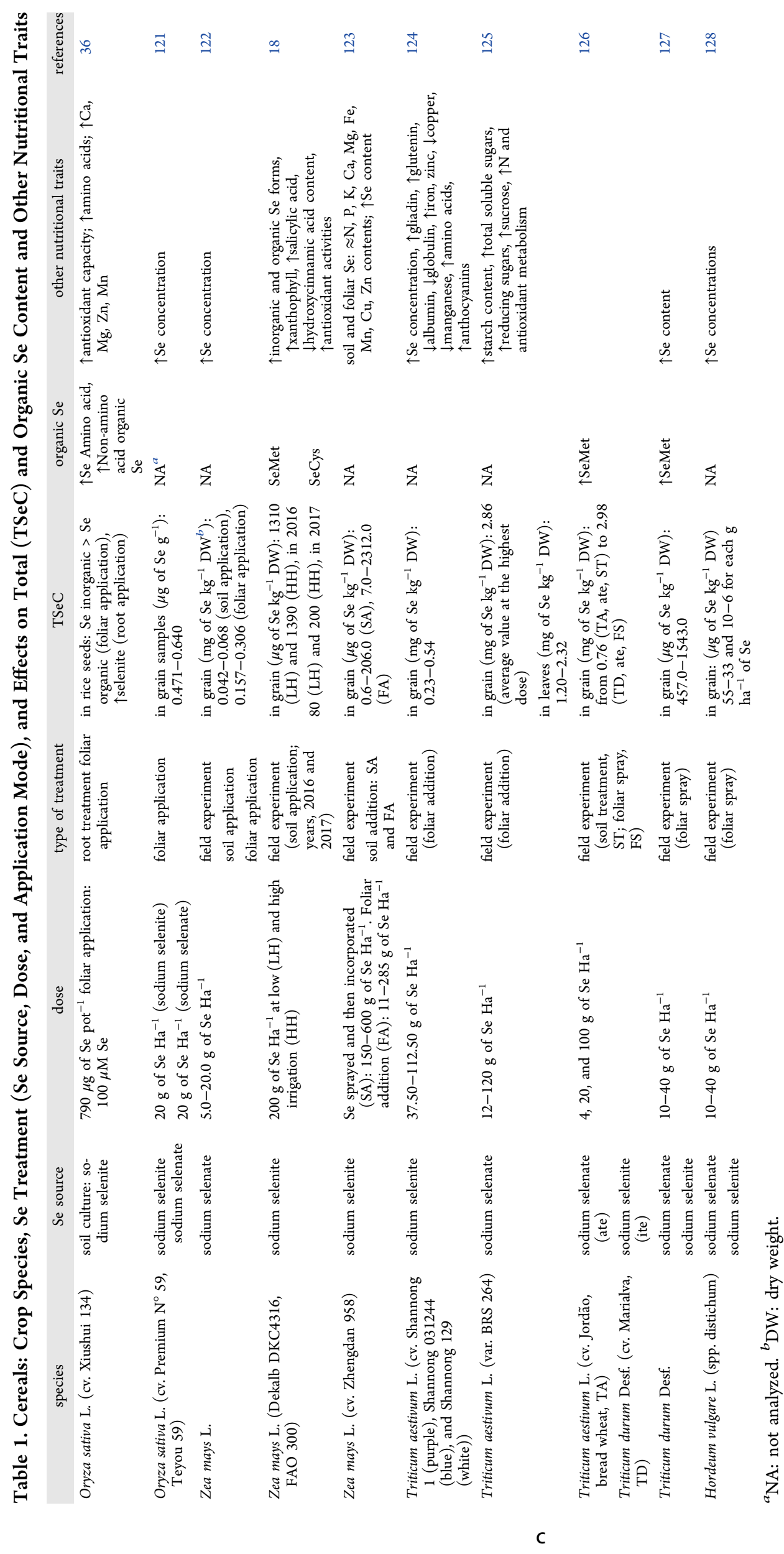


193 fertilizer form, crop species, and variety and growth stage, to 194 name a few. Indeed, Se species distribution in soils shows that, 195 after irrigation, selenate can be considered as an easily available 196 short-term pool of Se for plants. The long-term pool of Se in 197 the topsoil mainly consists of selenite and organic Se species. 198 These species are readily retained but still sufficiently mobile to 199 be taken up by plants. The formation of elemental Se can be 200 considered as a nonavailable Se pool and is thus the major 201 cause of Se immobilization and long-term enrichment of Se in 202 soils. $^{28}$ In this sense, two years of selenite fertigation in maize 203 (Zea mays L.) increased the content of inorganic and organic $204 \mathrm{Se}$ forms, ${ }^{18}$ while irrigation did not affect Se concentration. In 205 rice, selenite uptake promoted organic Se accumulation, but 206 this was mainly stored in roots, a nonedible part of the plant. 207 On the contrary, selenate uptake resulted in the accumulation 208 of selenate in the higher part of the shoots, which is an 209 essential requirement for Se to be transported to the grain. ${ }^{29}$ 210 Foliar application is a valid alternative for Se enrichment of 211 agricultural products. ${ }^{30}$ Compared to Se fertilization to the soil, 212 foliar application by-passes any interference due to soil 213 chemistry and microbiology issues, ensuring a higher efficacy 214 even with low volumes of Se solution. Foliar application of 215 selenite or selenate has been successfully performed to increase 216 the Se content in many crops. ${ }^{30,31}$ Furthermore, the technique 217 paves the road toward the enrichment of plants by costly stable 218 isotopes, which are useful tools in plant physiology research.

219 In hydroponic systems, as it may be the case in the 220 production of soil-less vegetables and microscale vegetables, Se 221 can be supplied to the water or the nutrient solution. ${ }^{32,33}$

222 As far as the plant growth stage is concerned, Se may be 223 applied all at once or repeatedly and from sowing to stem 224 elongation, with different outcomes in terms of Se accumu225 lation and partitioning among plant organs. ${ }^{34,35}$ At the 226 vegetative stage, root application of selenomethylselenocys227 teine (SeMeSeCys) caused the highest water extractable Se 228 content in leaves with major a contribution from organic Se 229 species such as Se amino acid and non-amino acid organic Se. 230 Further investigation at the reproductive stage revealed that 231 foliar application of selenite resulted in the highest total Se 232 content in rice seeds, which was largely attributed to inorganic 233 Se. In contrast, the root application of selenite led to the 234 maximum accumulation of organic Se compounds, which are 235 the most beneficial to human health. ${ }^{36}$ The application of Se 236 during the booting stage resulted in the highest concentration 237 of Se in brown rice due to the highest upward translocation of 238 Se. More than $90 \%$ of Se in brown rice was accounted for by 239 organic species, mainly SeMet. The proportion of SeMet in the 240 brown rice decreased with the delay in application time. ${ }^{37}$ In 241 potatoes, foliar application of selenite during the tuber bulking 242 stage was appropriate for the production of Se-rich potatoes. ${ }^{34}$ 243 In broccoli, Se fortification at developmental stages increased $244 \mathrm{SeMeSeCys}$ content. $^{38}$

245 Finally, the environmental factors (soil characteristics, 246 rainfall, and temperature regimes, etc.) and the cultivation 247 practices (sowing date, fertilization and irrigation schedules, 248 use of growth stimulators, etc.) may greatly affect the Se uptake 249 and partitioning among plant organs. Moreover, both environ250 mental stresses and Se may interfere in affecting the content of 251 secondary metabolites in plant tissues.

252 For all the aforementioned reasons, reviewing the literature 253 available on Se-biofortified foods is not easy, and any effort to 254 regroup treatments and effects may give arbitrary interpreta255 tions that may be questionable. In light of this, the last 10 years of literature is summarized in Tables $1-11$, regrouping plant $256 \mathrm{t} 1$ foods by crop types (arable crops, vegetables, microscale 257 vegetables, and fruit trees) and pointing out, for any reference, 258 the plant species and cultivar; the Se source, dose, and 259 application mode; and the main effects of Se biofortification in 260 terms of total and organic Se content and other nutritional 261 traits (such as bioactive compounds and antioxidant activity). 262 Only literature dealing with the content of Se species in edible 263 portions of plants is considered here, neglecting references 264 focused on the effect of Se on plant physiology, biochemistry, 265 and molecular biology. Finally, Table 12 summarizes literature 266 on Se-enriched meat from livestock fed with Se-enriched feed. 267 Since cooking methods could imply losses of Se species, the 268 results reported in the following Tables $1-12$ are referred to 269 as raw products. Indeed, it has been estimated that around 270 13.5, 24.0, 3.1, and $46.9 \%$ of SeMet were lost during the 271 processes of steaming, boiling, frying, and milking, respectively, 272 while SeCys and SeMeSeCys were completely lost from boiled 273 cereals. $^{39}$

\section{SE-BIOFORTIFIED PLANT FOODS}

Arable Crops. Tables 1 and 2 report total and organic Se 276 t2 contents and effects on other nutritional traits of cereal and 277 legume grains, as affected by biofortification strategies. From 278 the results in Table 1 , it can be drawn that the fortifying 279 methods used in literature to enrich the crops (foliar spray and 280 soil application) are able to supply the grain with doses of Se 281 suitable for human nutrition; in particular, for rice, the higher 282 Se concentration in grain was achieved by absorbing Se from 283 roots in the form of selenite, while for all the other plant 284 species, the most efficient method of fortification was foliar 285 spray. The nutritional benefits that cereal grain may obtain 286 with Se fortification were an increase in antioxidant activity; a 287 nutrient content higher than in the control; and an increase in 288 amino acids, phenols, anthocyanins, sugars, and Se organic 289 forms. This seems to encourage further research on the 290 possible use of Se-fortified cereals in the diet.

291

Table 2 summarizes recent literature on Se biofortification in 292 legumes (bean, lentil, chickpea, and soybean). The results 293 obtained for legumes do not yet make completely clear the 294 nutritional benefits of Se fortification. Both selenite and 295 selenate, as well as both foliar spray and soil addition, are 296 effective in increasing Se content in seeds. Unfortunately, 297 information about the increase in the nutritional quality of Se- 298 enriched seeds is still lacking; however, the ascertained 299 presence of SeMet in chickpea and soybean seeds encourages 300 further research to deepen these studies.

Vegetable Crops. Much research was also conducted on 302 the Se fortification of lettuce and other leafy vegetables, such as 303 spinach, basil, endive, and chicory. The results are reported in 304 Tables 3 and 4.

The total Se concentration in the leaves of Se-treated lettuce 306 changed greatly, depending on the Se fertilizer (selenite or 307 selenate) and the method of Se-fortification used (Table 3). 308 The most important benefits due to Se fortification were a 309 decreased nitrate content; an elevated lettuce quality and 310 yield; $^{40-43}$ an increased leaf area, dry weight, pigment content, 311 and antioxidant enzyme activity; ${ }^{42-44}$ a slightly higher shelf life 312 with respect to the control; ${ }^{45}$ an enhanced $\mathrm{N}$ and/or $\mathrm{S} 313$ metabolism or total sugar content; ${ }^{46-48}$ and an increased stress 314 tolerance. $^{49}$ As far as lettuce is concerned, the risk of reaching 315 total Se concentrations in the leaves that is too high for the 316 
human diet seems to be excessive compared to the little 317 evident nutritional benefits.

For spinach, the only total Se concentration values suitable 319 for human nutrition were those reported by Ferrarese et al., ${ }^{50} 320$ who found concentrations in the leaves ranging from 9.3 to 321 $15.5 \mu \mathrm{g}$ of Se $\mathrm{kg}^{-1}$ DW (Table 4). The only benefit of Se 322 fortification shown in these works was an increase of the 323 antioxidant capacity, and actually, an increase of growth 324 parameters has been found to occur only with Se doses ${ }^{51}$ too 325 high to be used for products suitable for human consumption. 326 The studies on basil showed that the benefits due to Se 327 fortification included an enhancement of carotenoids, soluble 328 phenols, proline, and anthocyanin, ${ }^{52,53}$ whereas contrasting 329 effects on biomass increase have been highlighted. ${ }^{53,54}$ The 330 essential oil content was not influenced by Se fortification. ${ }^{55} 331$ The nutritional benefits obtained from the biofortification of 332 basil have been achieved with doses of Se too high to be 333 compatible with human nutrition. However, this plant material, 334 which is rich in carotenoids, soluble phenols, proline, and 335 anthocyanin, could be used by mixing it with similar untreated 336 plant material to obtain a Se content suitable for human 337 diet. $^{52,53}$ The studies on chicory evidenced an increase in plant 338 yield and antioxidant compounds, such as ascorbic acid and 339 total phenolics.

Particularly relevant are the studies on the Se biofortification 341 of Brassicaceae (Table 5), as these leafy vegetables are Se- 342 ts hyperaccumulating plants.

Interestingly, of the beneficial Se amino acids, SeMetSeCys 344 was the only one identified in radish plants. This compound 345 has recognized anticarcinogenic properties; thus its accumu- 346 lation in radish roots is a valuable result. Plants sprayed with Se 347 produced more SeMetSeCys compared to plants grown in 348 hydroponics. The contents of Cys, polyphenols, and 349 glutathione in Se-treated plants were higher than in the 350 untreated plants. Concerning cabbage, both the total Se 351 content and some nutritional traits of the edible parts increased 352 after Se biofortification; in florets, Bañuelos et al. ${ }^{56}$ found 353 higher percentages of Se organic compounds (such as SeMet 354 and $\mathrm{MeSeCys)}$ than those of Se inorganic compounds. Also, 355 Sindelárová et $\mathrm{al}^{57}$ found the presence of Se organic 356 compounds, such as SeMet and SeMetSeCys, in all the parts 357 of the Se-biofortified plants and reported that Se accumulated 358 mainly in the flower heads. Mechora et al. ${ }^{58}$ reported that the 359 main soluble species in the Se-biofortified plants was SeMet, 360 even if the major amount of Se was in insoluble forms (31- 361 $53 \%)$. Ramos et al. ${ }^{59}$ reported that half of the total Se 362 accumulated in leaves was SeMetSeCys and SeMet, the total 363 glucosinolate contents were not affected by the concentration 364 of selenate application, and the total antioxidant capacity of 365 plants was greatly stimulated by selenate. Mechora et al. ${ }^{60} 366$ reported that selenate addition had no effect on the amounts of 367 anthocyanins or chlorophyll. Leafy crops are the most suitable 368 for fortification studies; they require little time to reach 369 maturity, they can be grown in pots, and they easily allow for 370 the evaluation of the dose of the element that will be present in 371 the edible part. Among all the leafy crops mentioned above, the 372 most suitable for Se biofortification seem to belong to the 373 Brassicaceae family. Since these are Se-hyperaccumulating 374 plants, the main concern could be the risk of excessive doses of 375 Se in the edible parts. However, as demonstrated by the total 376 Se concentration values found by Mechora et al..$^{58,60}$ and 377 Sindelářová et al. ${ }^{57}$ on cabbage grown in fields and fertilized 378 with Se by soil addition or foliar spray, it should not be difficult 379 


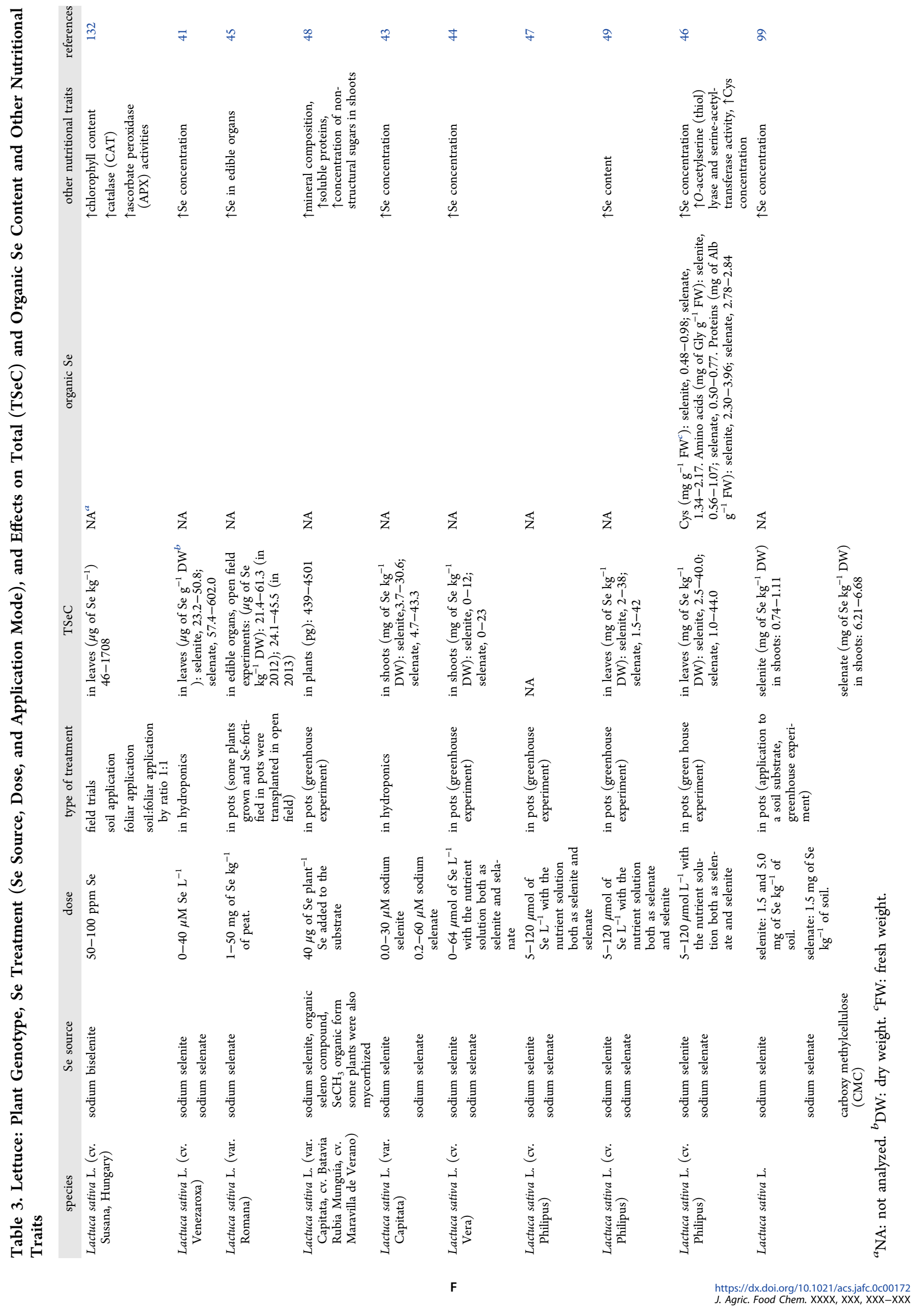




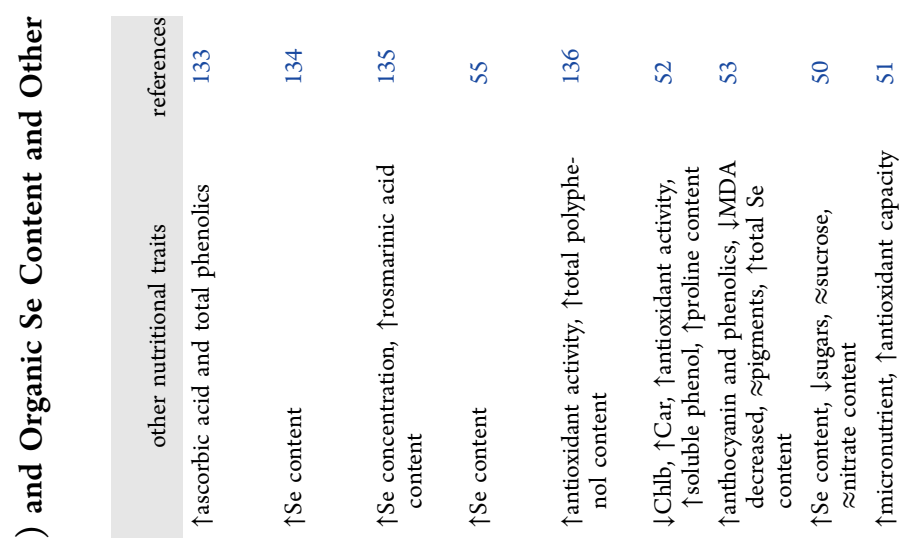

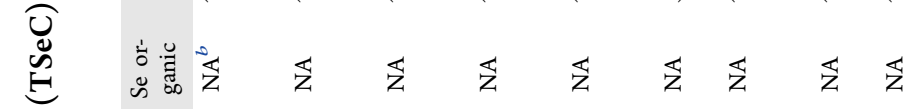
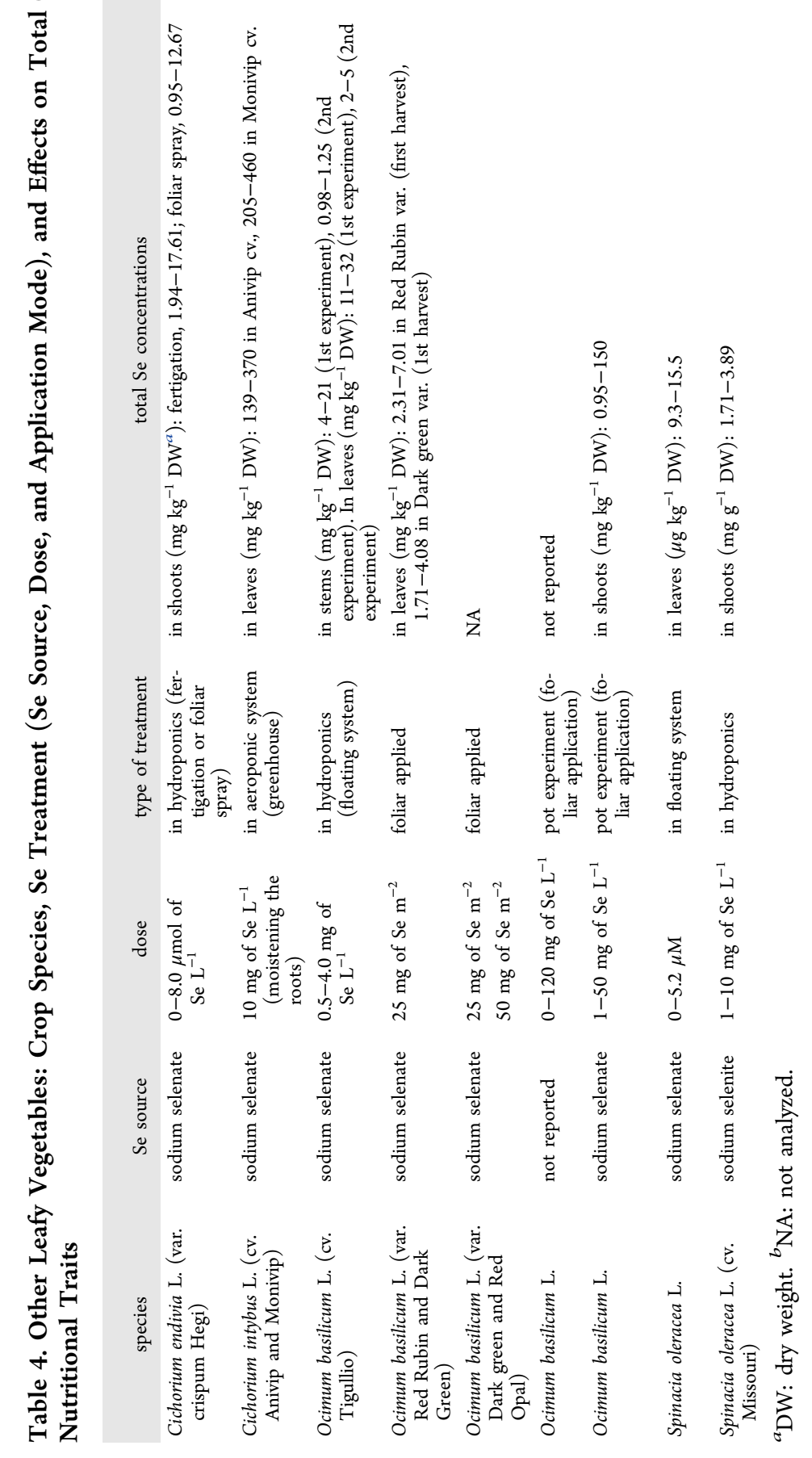


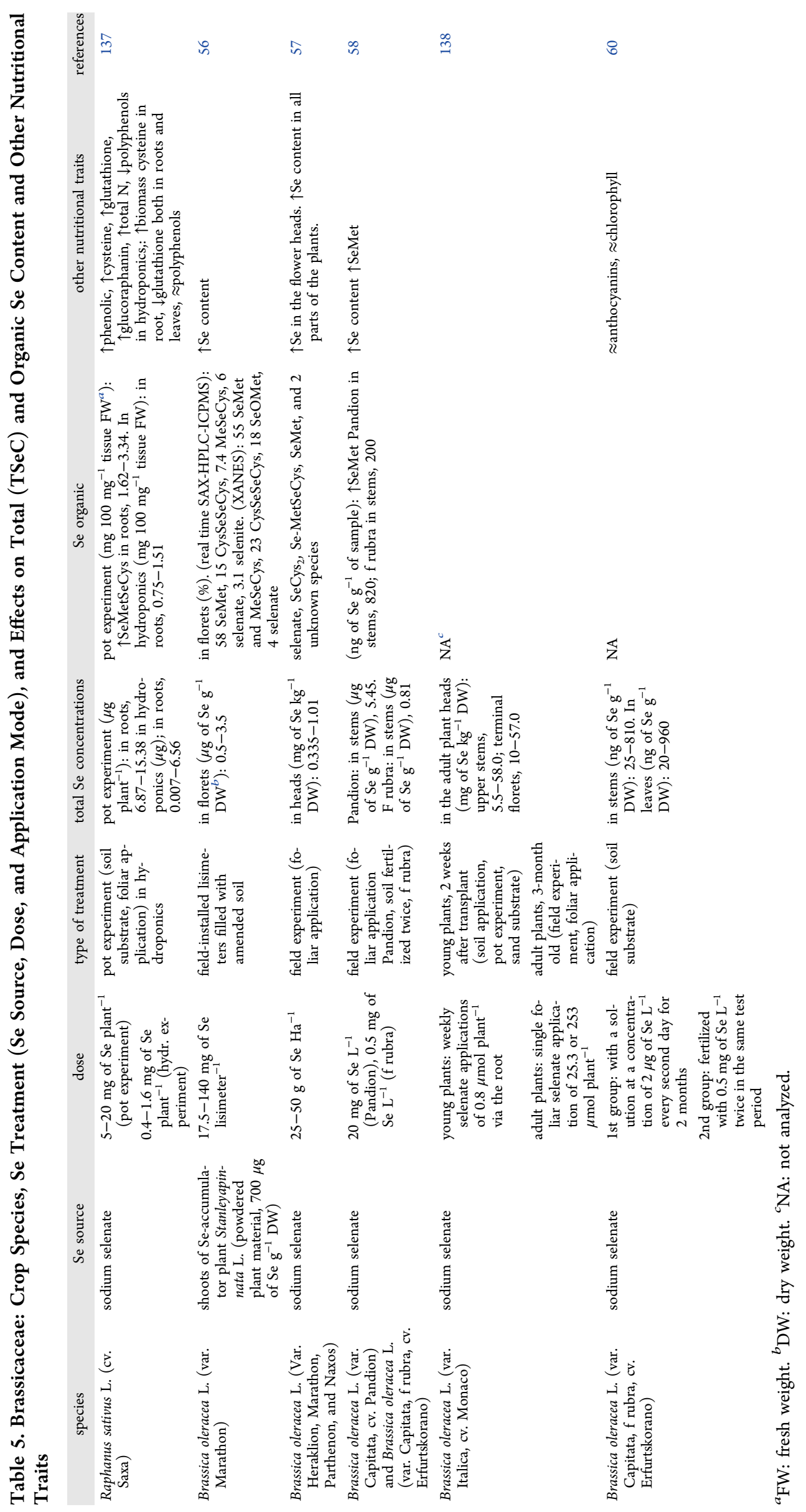




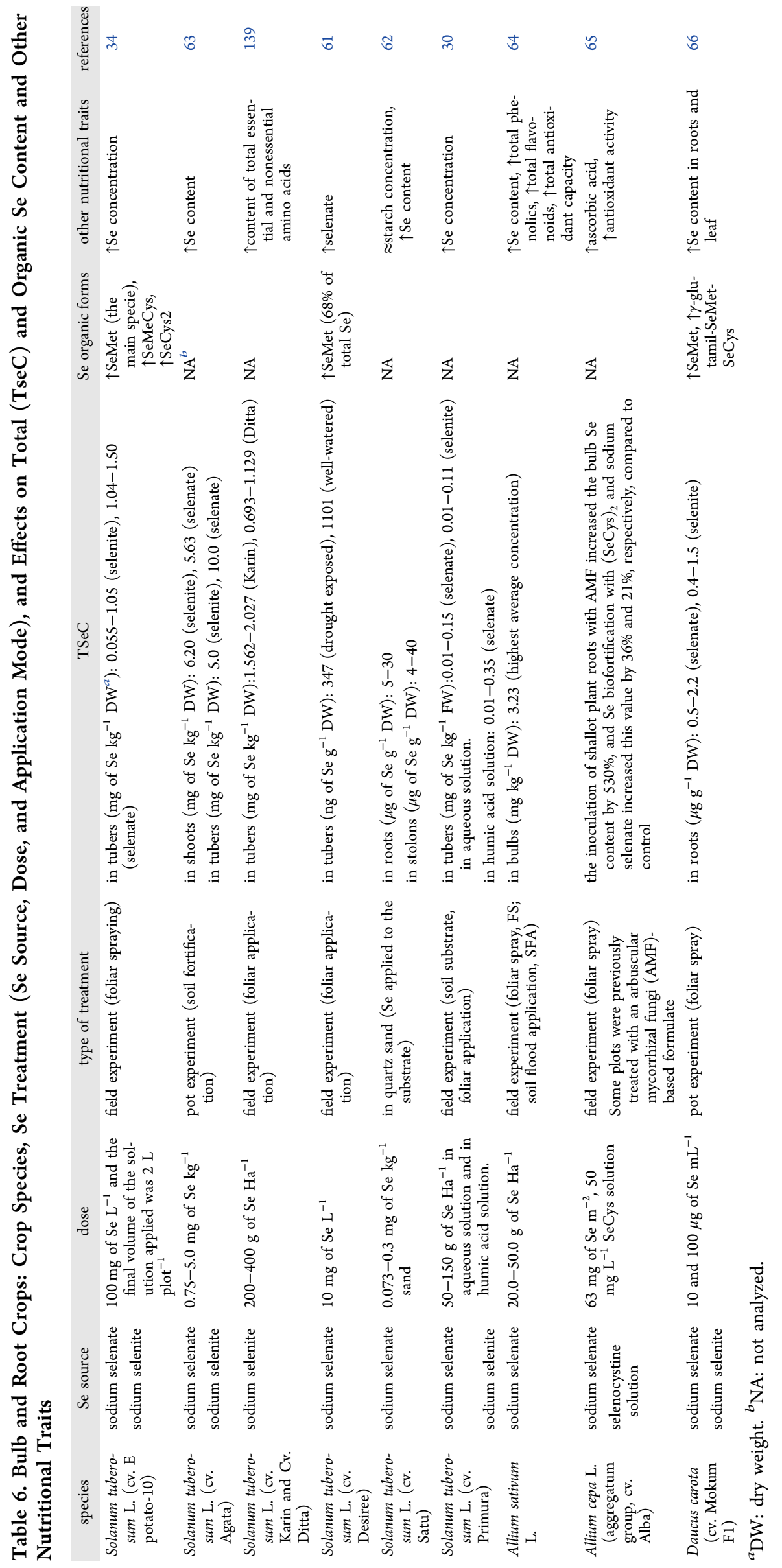




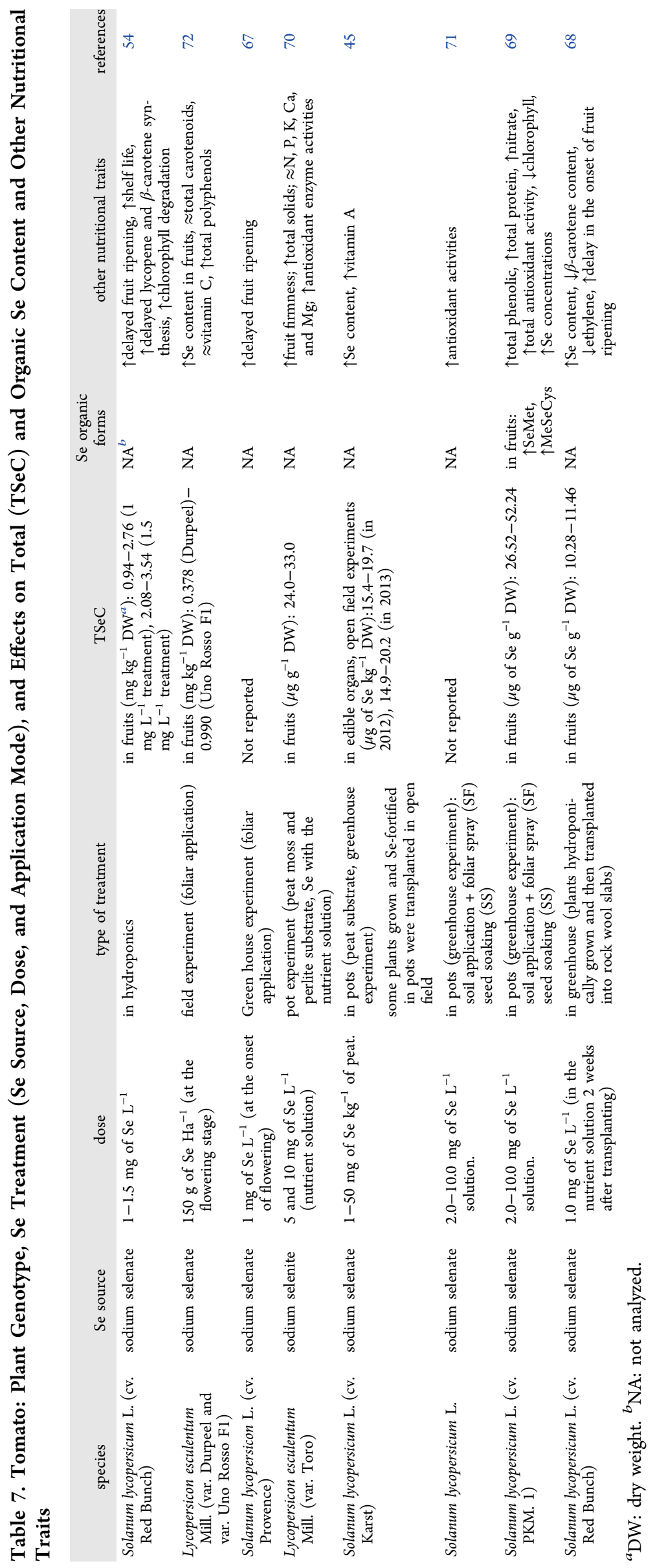


380 to develop an agronomic methodology to obtain leaves or 381 plant heads with the right dose of Se. These edible parts 382 contain, in addition to Se in inorganic forms, Se in organic 383 forms (SeMet and SeMetSeCys), which are more easily 384 available to the consumer. ${ }^{57,58,60}$

385 Se-biofortification studies were also carried out on plants 386 whose edible parts were tuber, bulb, or root (potato, garlic, 387 shallot, and carrot), and the obtained results are reported in 388 Table 6.

389 As far as the nutritional benefits are concerned, selenate was 390 the most efficient source for Se biofortification of tubers; ${ }^{34}$ the 391 accumulation of inorganic Se was higher in tubers treated with 392 selenate $(31.9 \%$ of the total Se content) than in those treated 393 with selenite $(1.5 \%) .^{34}$ However, selenate was markedly 394 inferior to selenite in terms of the organic transformation 395 rate of Se. ${ }^{34}$ Selenate and SeMet were the main soluble Se 396 species in potato tubers. ${ }^{61}$ In tubers, plant application of Se 397 increased the relative content of total essential and 398 nonessential amino acids compared to the controls (phenyl399 alanine was enhanced particularly). ${ }^{62}$ When applied in small 400 doses, Se provided beneficial effects on the tuber production, 401 activated enzymes of the antioxidant system, ${ }^{63}$ and delayed 402 aging of the stolons and roots, contributing to an increased 403 shelf life of potatoes. ${ }^{61}$ At harvest, the starch concentration in 404 tubers did not change. ${ }^{61}$ In garlic, foliar spray was more 405 effective than soil application. A significant increase in total 406 phenolics, total flavonoids, and total antioxidant capacity was 407 observed in bulbs. ${ }^{64}$ Concerning shallots, it was reported that 408 Se biofortification combined with pretreatment of an 409 arbuscular mycorrhizal fungi (AMF)-based formulate increased 410 the bulb Se content by 530\%, while Se biofortification with 411 selenocystine $\left(\mathrm{SeCys}_{2}\right)$ and selenate increased this value by $41236 \%$ and $21 \%$, respectively, compared to the control. The 413 values of bulb quality indicators, macro- and microelements, 414 ascorbic acid, and antioxidant activity increased upon AMF 415 inoculation; ${ }^{65}$ both selenite and selenate positively affected 416 most of the quality attributes and macroelements as well as the 417 contents of Se and ascorbic acid. For carrots, inorganic Se, 418 SeMet, and $\gamma$-glutamil-SeMet-SeCys were the predominant Se 419 forms in roots. 66

420 In Italy, potatoes, onions, and carrots containing low 421 concentrations of Se (suitable for human diet) are already in 422 trade and are produced by the Italian Potatoes of Quality 423 Consortium, with headquarters in Bologna. ${ }^{30}$ Since tubers, 424 bulbs, and roots are poor but nutritious foods, improving their 425 nutritional characteristics even by increasing their content of $426 \mathrm{Se}$ in organic forms appears relevant for the wellness of 427 populations of the poorest areas of the world. .

428 As far as fruit vegetables are concerned, the plant most 429 commonly used in Se biofortification studies was tomato, 430 whose results are reported in Table 7 . Biofortification with Se 431 seemed to cause a delay in the onset of the fruit 432 ripening. ${ }^{54,67,68}$ This effect may be positive because it could 433 affect the postharvest shelf life of tomatoes; Zhu et al. ${ }^{67}$ 434 reported that this could be due to an inhibition of reactive 435 oxygen species (ROS) generation by stimulation of antioxidant 436 defense systems, together with a downregulation of ethylene 437 biosynthesis genes. Similarly, Puccinelli et al. ${ }^{54}$ noticed a lower 438 respiration rate and ethylene production, associated with a 439 delayed lycopene and $\beta$-carotene synthesis and chlorophyll 440 degradation. The nutritional benefits that tomato fruits 441 acquired with Se biofortification were the presence of SeMet 442 and MetSeCys as the major forms of Se compounds in the fruits, ${ }^{69}$ an increase of the antioxidant activity, ${ }^{70,71}$ a slightly 443 higher level of vitamin $\mathrm{A},{ }^{45}$ and an increase in fruit firmness 444 and fruit total solids. ${ }^{70}$ Se biofortification of tomatoes may be 445 interesting for fortified food producers. Also, in this case, it is 446 essential to develop an agronomic method that allows fruits to 447 be obtained with a dose of Se suitable for the human diet. 448 Particularly interesting, from this point of view, is the 449 fortification technique developed by Businelli et al., ${ }^{45}$ which 450 is as follows: (i) enrich an appropriate amount of peat in Se, 451 (ii) sow the seeds of the selected crop species in Se-enriched 452 peat until seedlings have the appropriate size for transplanting, 453 (iii) transfer these Se-enriched transplants in the field. 454 Moreover, using this technique, the environmental spread of 455 Se is minimized, as this element is not in any way distributed in 456 the field, but it is only used during the pre-transplanting stage 457 and is immediately absorbed by the seedlings. Another on-field 458 fortification technique, suitable for obtaining a Se-fortified 459 tomato without excessive Se concentrations, is that proposed 460 by Andrejiová et al. ${ }^{72}$ The Se fortification of tomatoes has 461 potential for obtaining a table fruit with a longer shelf life and 462 with high levels of Se-organic forms and antioxidant 463 compounds. Another possible use could be the production of 464 sauce; in this case, Se-fortified tomatoes could be mixed with 465 untreated tomatoes in order to avoid excessive Se concen- 466 trations in the final product.

Microscale Vegetables. Recent studies on Se biofortifi- 468 cation were focused on "microscale vegetables", i.e., plants in 469 early growth stages, since they are able to absorb relevant 470 amounts of $\mathrm{Se}^{73}$ and are naturally rich in phytochemicals. ${ }^{74-76} 471$ Microscale vegetables differ from each other according to their 472 corresponding growing cycle lengths, plant heights, edible 473 portions, and other secondary traits. ${ }^{74,76}$ This section will 474 review only literature on sprouts (i.e., 3-5 day-old seedlings), 475 grasses (7-12 day-old seedlings from Graminaceae species), 476 and microgreens (5-10 day-old seedlings from all plant 477 species except for Graminaceae species). These require a short 478 time interval to be produced ( $1-3$ weeks) and few inputs (i.e., 479 no soil, only water, and no or low light). ${ }^{74,76}$ Tables $8-10480$ t8 report the studies of the last ten years that concern the most 481 exploited technique for Se biofortification in sprouts, grasses, 482 and microgreens: Se is supplied by (i) the germination 483 substrate (Table 8), (ii) the soaking procedure (Table 9), and 484 t9 (iii) the chemical priming (Table 10). All the tables report the 485 effect of these methods on total and organic Se content and, 486 where studied, on phytochemicals.

487

All the procedures used for Se biofortification generally 488 cause an increase of Se content, but results varied with the 489 species; the growth stage; and the Se source, dose, timing of 490 application.

491

The growth stage should be chosen accurately since it is 492 related to the edible portion of the plant. In the case of sprouts, 493 the whole seedling (shoots and roots) is edible, while in the 494 case of microgreens and grass, only the shoot is used in human 495 nutrition (i.e., for salads, soups, or juices). ${ }^{75,76} 496$

The organ to be consumed may also depend on the form of 497 Se used for biofortification. In fact, by using sodium selenite 498 $\left(\mathrm{Na}_{2} \mathrm{SeO}_{3}\right)$, the Se might be highly accumulated in the roots 499 (i.e., mainly as selenite), while by using sodium selenate 500 $\left(\mathrm{Na}_{2} \mathrm{SeO}_{4}\right)$, the Se will be accumulated mainly in the shoots as 501 selenate and organic Se. ${ }^{29,77}$

The Se source used for biofortification is strongly related to 503 the chemical form of Se consumed by nutrition. On the other 504 hand, the chemical product containing $\mathrm{Se}$ is often chosen 505 


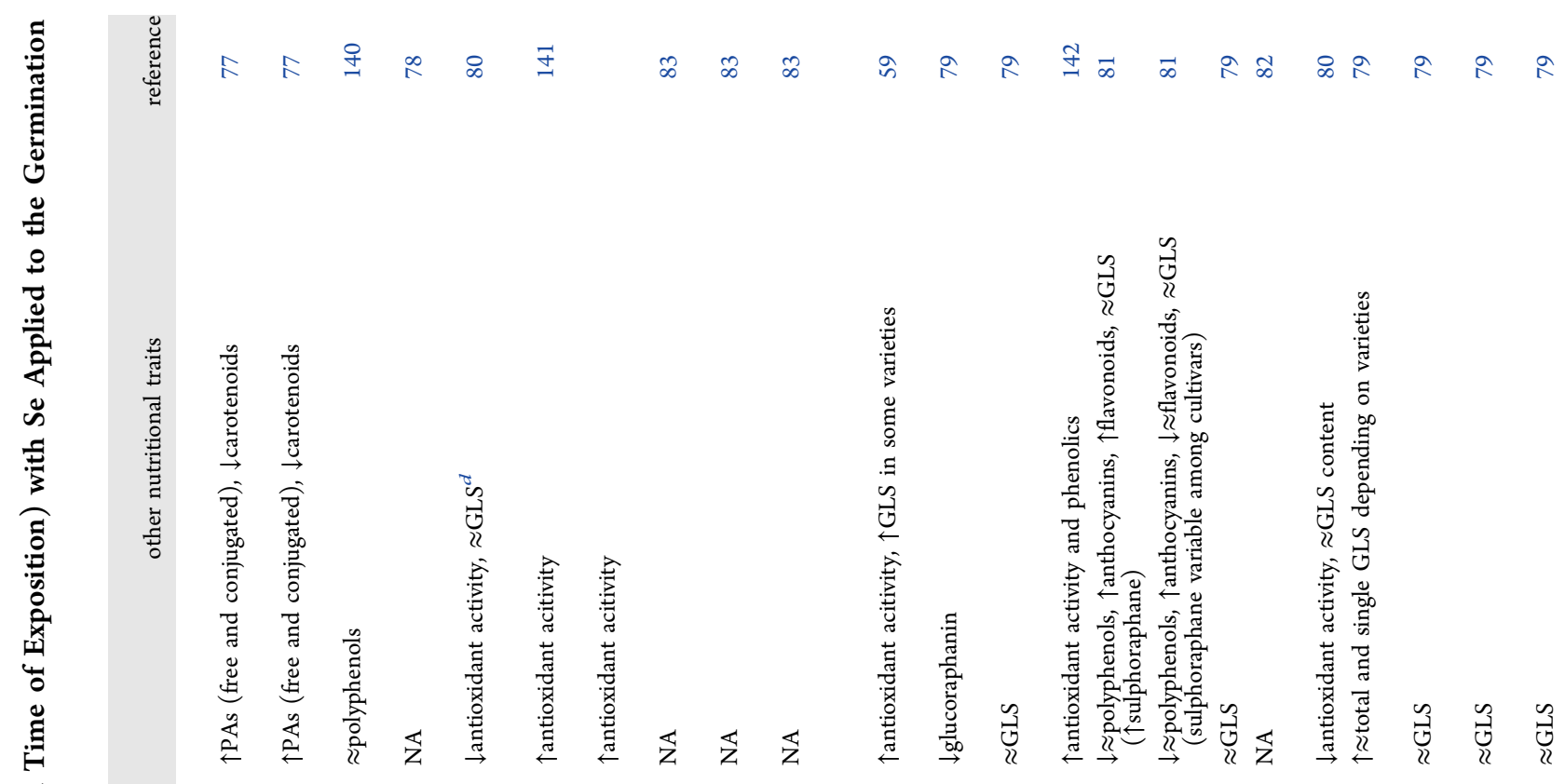

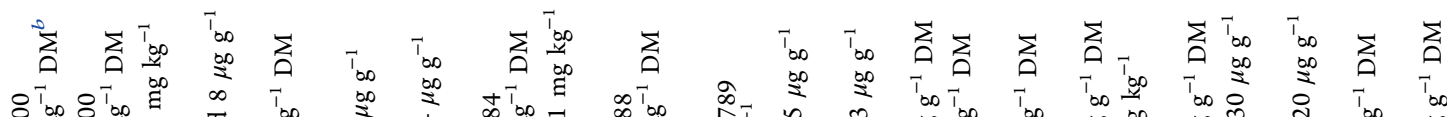

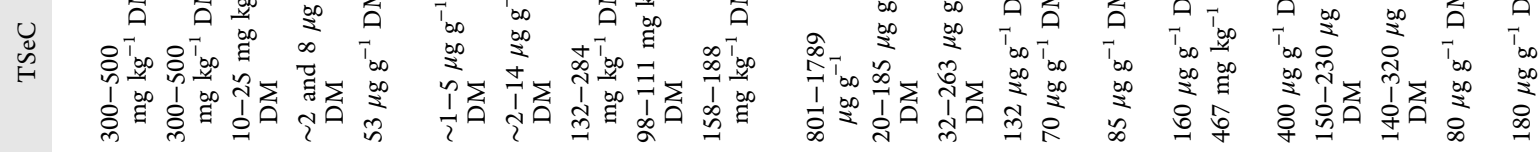

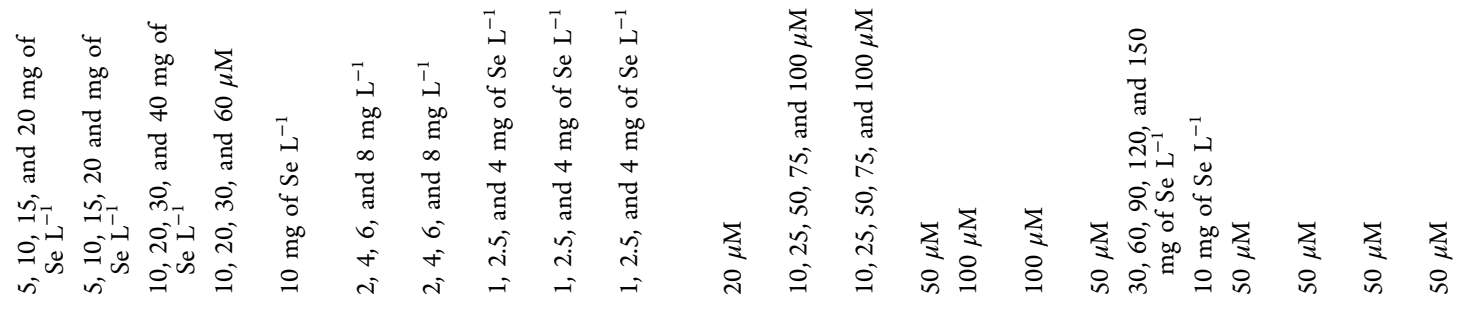

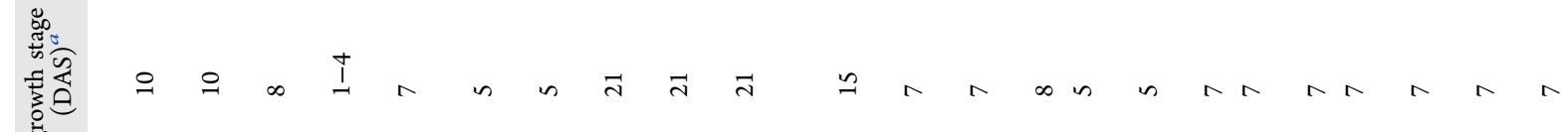




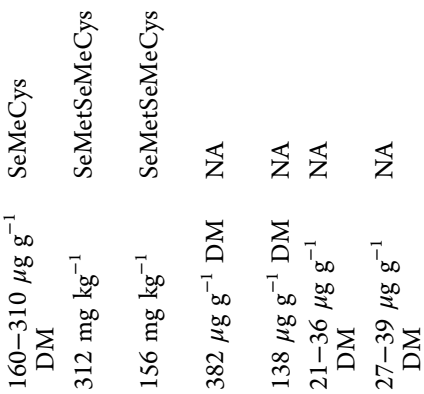

according to cost-effective parameters. Within the existing 506 compounds suitable for Se biofortification, inorganic ones 507 (e.g., sodium selenite and sodium selenate) are known to be 508 cheap and efficient, whereas organic ones (i.e., selenoamino 509 acids) are expensive but more relevant for human nutrition. ${ }^{77} 510$ Since plants are able to produce selenoproteins starting from 511 inorganic Se compounds, inorganic forms are the most 512 preferred for Se biofortification, ${ }^{77}$ as demonstrated by scientific 513 literature reported in Tables $8-10$.

As far as the Se dose is concerned, studies are needed to 515 individuate the optimal dose, i.e., the dose that increases Se 516 accumulation and phytochemical concentration without 517 compromising seedling growth in order to maximize the 518 yield of total and organic Se and of phytochemicals. It should 519 be noted that very high Se doses are not worthwhile since they 520 depress plant growth and may cause very high Se 521 concentrations, which may limit the consumption of micro- 522 scale vegetables in order to not exceed the recommended daily 523 Se intake.

Finally, the method and time of exposure for Se 525 biofortification treatment significantly affect the final results 526 in terms of Se and phytochemical contents. Concerning Se 527 application via the germination solution, the common 528 procedure consists of sowing seeds on the substrate containing 529 different solutions of Se until the day of harvest (Table 8). 530 Since the germination period may vary between 5 and 15 days, 531 the solution in the substrate has to be restored often, especially 532 when the trays for sprouting are open. Some authors added a 533 specific volume of the corresponding Se solution to restore the 534 solution content, ${ }^{78,79}$ and others sprinkled or sprayed the Se 535 solution at specific times. ${ }^{80,81}$ When possible, due to the long 536 duration of the germination period (i.e., 1521 days), some 537 authors changed the nutrient solution containing Se. ${ }^{59}$ The 538 choice is also affected by the presence ${ }^{78,82}$ or absence ${ }^{77,83}$ of 539 the substrate (i.e., paper, sand, etc.). Different procedures 540 imply differences in the evolution of Se concentration in the 541 germination substrate, and as a consequence, the results in the 542 literature are often not comparable.

543

Considering the soaking (Table 9) and priming with Se 544 (Table 10), the main variations are due to the time of 545 exposition to the treatment. In the case of soaking, the time of 546 treatment may vary from 4 to $24 \mathrm{~h}$ depending on the size of 547 seeds, and Se content generally increases with increasing time 548 of exposition. Studies on priming with Se did not report results 549 concerning the content of total Se and Se proteins, probably 550 because these studies were more focused on plant growth 551 parameters and stress resistance than on nutritional traits. $\quad 552$

In addition to the aforementioned techniques, the recent 553 work of Puccinelli et al. is noteworthy, ${ }^{84}$ in which they 554 reported the possibility of producing Se-enriched sprouts from 555 seeds harvested by a mother crop fertilized with Se. This might 556 represent an innovative method to produce Se-enriched 557 microgreens.

Fruit Tree Crops. Despite the considerable knowledge of 559 Se effects and accumulation on herbaceous species, little is 560 known about trees species. In particular, the present section 561 will focus just on Se effects on fruits and their derivates, as little 562 evidence has been reported on Se accumulation especially in 563 the edible fruits and their derivates (juice, wine, and oil) 564 (Table 11). The content of Se in tree plants can be increased 565 t11 in different ways, including soil and foliar fertilization. From 566 the bibliography examined, it emerges that the most used 567 modality for Se biofortification in tree plants is the foliar spray. 568 


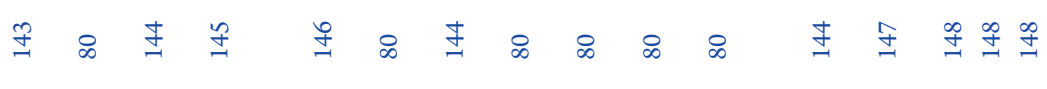

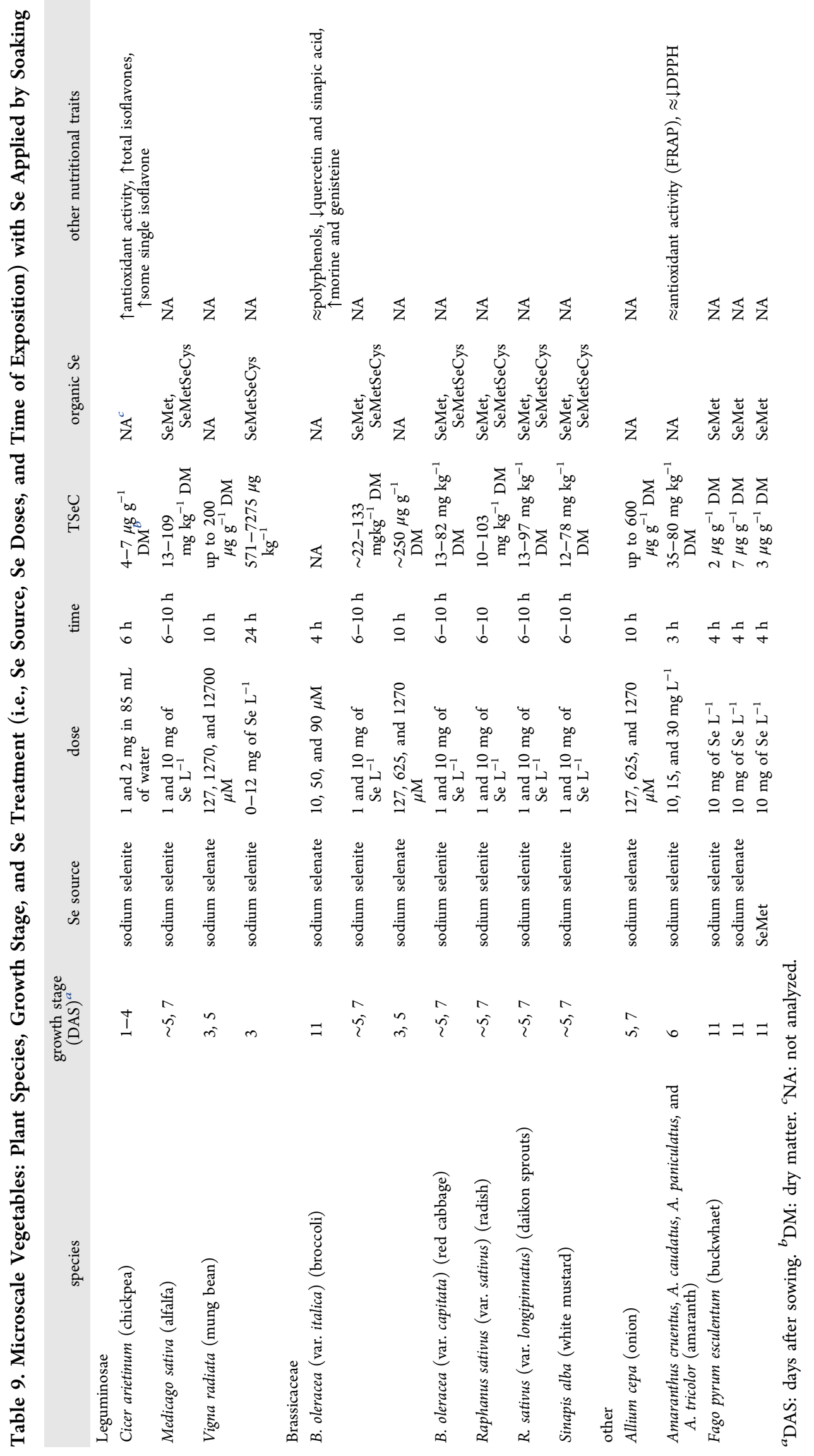


Table 10. Microscale Vegetables: Plant Species, Growth Stage, and Se Treatment (i.e., Se Source, Se Doses, and Time of Exposition) with Se Applied by Priming

\begin{tabular}{|c|c|c|c|c|c|c|c|c|}
\hline species & $\begin{array}{l}\text { growth stage } \\
(\text { DAS })^{a}\end{array}$ & Se source & dose & time & $\mathrm{TSeC}$ & $\underset{\mathrm{Se}}{\text { organic }}$ & phytochemicals & reference \\
\hline \multirow{4}{*}{$\begin{array}{l}\text { Oryza sativa } \\
\text { (rice) }\end{array}$} & 5,10 & sodium selenite & 0.8 and $1 \mathrm{mg}$ of $\mathrm{Se}^{-1}$ & $24 \mathrm{~h}$ & $\mathrm{NA}^{b}$ & NA & $\downarrow$ polyphenols & 149 \\
\hline & 18 & sodium selenite & $\begin{array}{l}15,30,45,60,75,90 \text {, and } \\
105 \mu \mathrm{mol} \text { of } \mathrm{Se} \mathrm{L}^{-1}\end{array}$ & $24 \mathrm{~h}$ & NA & NA & $\begin{array}{l}\approx \text { polyphenols (slight increase at } \\
\text { the highest Se dose) }\end{array}$ & 150 \\
\hline & 7 & not specified & $60 \mu \mathrm{M} \mathrm{Se}$ & $24 \mathrm{~h}$ & NA & NA & NA & 151 \\
\hline & 18 & not specified & $60 \mu \mathrm{M} \mathrm{Se}$ & $24 \mathrm{~h}$ & NA & NA & $\uparrow$ antioxidant activity & 152 \\
\hline $\begin{array}{l}\text { Triticum } \\
\text { aestivum } \\
\text { (wheat) }\end{array}$ & 18 & sodium selenate & $0,25,50,75$, and $100 \mu \mathrm{M} \mathrm{Se}$ & $30 \mathrm{~min}$ & NA & NA & NA & 153 \\
\hline
\end{tabular}

569 In general, foliar spraying was preferable in comparison to soil 570 application, since it involves a more efficient uptake of Se, an 571 absence of residual effects, and a minimum consumption of Se 572 salts, resulting in the most environmentally safe and 573 economically acceptable method. ${ }^{31,85}$ A little-explored treat574 ment modality is that of fruit treatment. Pezzarossa et al. ${ }^{86}$ 575 investigated the effects of foliar and fruit spraying of sodium 576 selenate on Se accumulation, fruit growth, and senescence in 577 peach and pear fruit crops. Both treatments increased the fruit 578 Se concentration, but fruit treatment was more effective than 579 leaf treatment in increasing Se content in fruits. The daily 580 consumption of pears and peach treated with $1 \mathrm{mg}$ of Se $\mathrm{L}^{-1}$ 581 does not induce toxicity but can even provide a rational $\mathrm{Se}$ 582 supplementation for human nutrition. Se accumulated in the 583 pear juice was almost all inorganic, so the application of 584 selenite is considered more suitable than selenate from the 585 viewpoint of food safety. ${ }^{87}$ In apples and pomegranates, Se 586 supplementation via foliar spray enhanced fruit quality. ${ }^{88,89}$ In 587 particular, in apples, in addition to the increase of Se content, 588 an increase in the flesh firmness, titrable acidity, soluble solid 589 content, and activities of antioxidant enzymes were observed, ${ }^{90}$ 590 while in pomegranates, Se fertilization led to an important 591 increase of the content of phenolic compounds, antioxidants, 592 and anthocyanins. 89

593 Regarding the effects of Se supplementation $\left(100 \mathrm{mg} \mathrm{L}^{-1}\right.$ via 594 foliar spray) in table olives, D'Amato et al. ${ }^{91}$ reported that, at 595 harvesting time, the concentration in the edible part of the 596 drupes delivered $6.1 \mu \mathrm{g} \mathrm{g}^{-1}$, corresponding to $29 \mu \mathrm{g}$ of Se per 5 597 olives (39 and $49 \%$ of the recommended dietary allowance 598 (RDA) for adult men and women, respectively), and such 599 enrichment also changed the nutritional quality of the drupes, 600 with significant increases in the concentrations of $\mathrm{B}, \mathrm{Na}, \mathrm{Mg}$, $601 \mathrm{~K}, \mathrm{Cr}, \mathrm{Mn}, \mathrm{Fe}$, and $\mathrm{Cu}$ compared to the untreated control 602 group. Therefore, in addition to Se, the consumption of $10 \mathrm{~g}$ of 603 Se-enriched olives (five olives) per day per person would 604 provide a quantity of $\mathrm{Cu}, \mathrm{K}, \mathrm{Fe}, \mathrm{Mg}, \mathrm{Mn}$, and $\mathrm{Zn}$ equal to 3, 9, $6051,1,1$, and $0.5 \%$ of the RDA, respectively. ${ }^{92}$

606 Se fertilization via foliar spray $\left(50,100\right.$, and $\left.150 \mathrm{mg} \mathrm{L}^{-1}\right)$ is 607 also effective for the enrichment of extra virgin olive oil 608 (EVOO) in Se content (up to $120 \mu \mathrm{g} \mathrm{kg}^{-1}$ ). ${ }^{31,93}$ Moreover, Se 609 fertilization increased SeMet, carotenoid, chlorophyll, and 610 phenol content in EVOO. ${ }^{93,94}$ In particular, the phenolic 611 profiles showed that oleacein, ligustroside aglycone, and 612 oleocanthal were the most affected compounds and were 613 increased by 57, 50, and 32\%, respectively. All these 614 compounds, especially oleacein, have been shown to exert a 615 relevant antioxidant activity, contributing to both the shelf life 616 of EVOOs and positive effects on human health. ${ }^{93}$ It is 617 important to underline that foliar spray with Se may be particularly useful with EVOOs characterized by a poor 618 phenolic profile, which cannot meet the European Food Safety 619 Authority (EFSA) statement about the admissibility of the 620 health claim for EVOOs. Indeed, a well-planned Se fertilization 621 before flowering may help these EVOOs reach the minimum 622 content of hydroxytyrosol and its derivatives (e.g., the 623 oleuropein complex and tyrosol).

In vitis grapes, the acid invertase activity, total soluble sugar, 625 and Se content produced by plants treated with Se amino-acid- 626 chelated fertilizer were higher than in the untreated control. In 627 addition, Se fertilizer improved the nutritional characteristics, 628 including soluble sugar, soluble protein, soluble solid, and 629 reduced organic acid contents, while it had no effect on the 630 polyphenol antioxidants of Eurasian species. Moreover, Se 631 fertilization can be used not only to increase the Se content 632 and nutrition quality of grapes but also to reduce the 633 accumulation of heavy metals $\mathrm{Pb}, \mathrm{Cr}, \mathrm{Cd}, \mathrm{As}$, and $\mathrm{Ni}^{95,96} 634$

Immediately after the malolactic fermentation of Se-enriched 635 (100 $\mathrm{mg} \mathrm{L}^{-1}$ via foliar spray) grape berries, the wine obtained 636 from treated trees had a Se content of $0.620 \pm 0.09 \mathrm{mg}$ of Se 637 $\mathrm{L}^{-1} \cdot{ }^{97}$ In particular, the percentage of inorganic Se was $26 \%$ of 638 the total Se in the untreated wine, while in Se-enriched wine, 639 this percentage increased to $47.5 \%$ of the total Se. Selenite was 640 the inorganic chemical form most present in enriched wine, 641 probably due to the foliar application with selenate. Given a 642 daily wine consumption of $50 \mathrm{~mL}$, the contribution to the daily 643 Se RDA is remarkable, since it is 91 and $>100 \%$ for adult men 644 and women, respectively, as considered by FAO/IAEA/WHO 645 consultation, and 44 and $62 \%$ for adults, as considered by 646 USDA. In addition, the amount of alcohol contained in a 647 recommended volume of enriched Sangiovese wine is less than 648 the quantity referred to the moderate wine consumption 649 $\left(15.5-31 \mathrm{~g}\right.$ of alcohol day $\left.{ }^{-1}\right)$.

650

In general, foliar treatment with Se resulted in the effective 651 enhancement of Se content in fruits (olives, grapes, pears, 652 peachs, pomegranates, and apples) and their derivates (oil, 653 wine, and juice) and their nutritional quality. However, the 654 accurate planning of Se fertilization (time and dose) is 655 necessary in order to avoid damage to the photosynthetic 656 apparatus, inhibiting photosynthesis and the primary metab- 657 olism, and to maximize the protection from environmental 658 stresses and the products quality.

659

\section{SELENIUM SUPPLEMENTATION IN LIVESTOCK: EFFECTS ON MEAT QUALITY}

Se is an essential trace element in animal nutrition and exerts 662 multiple actions related to performance, fertility, health, and 663 product $_{\text {quality. }}{ }^{98}$ Different forms of Se supplements are 664 available for animal feed, and in particular, two major Se 665 


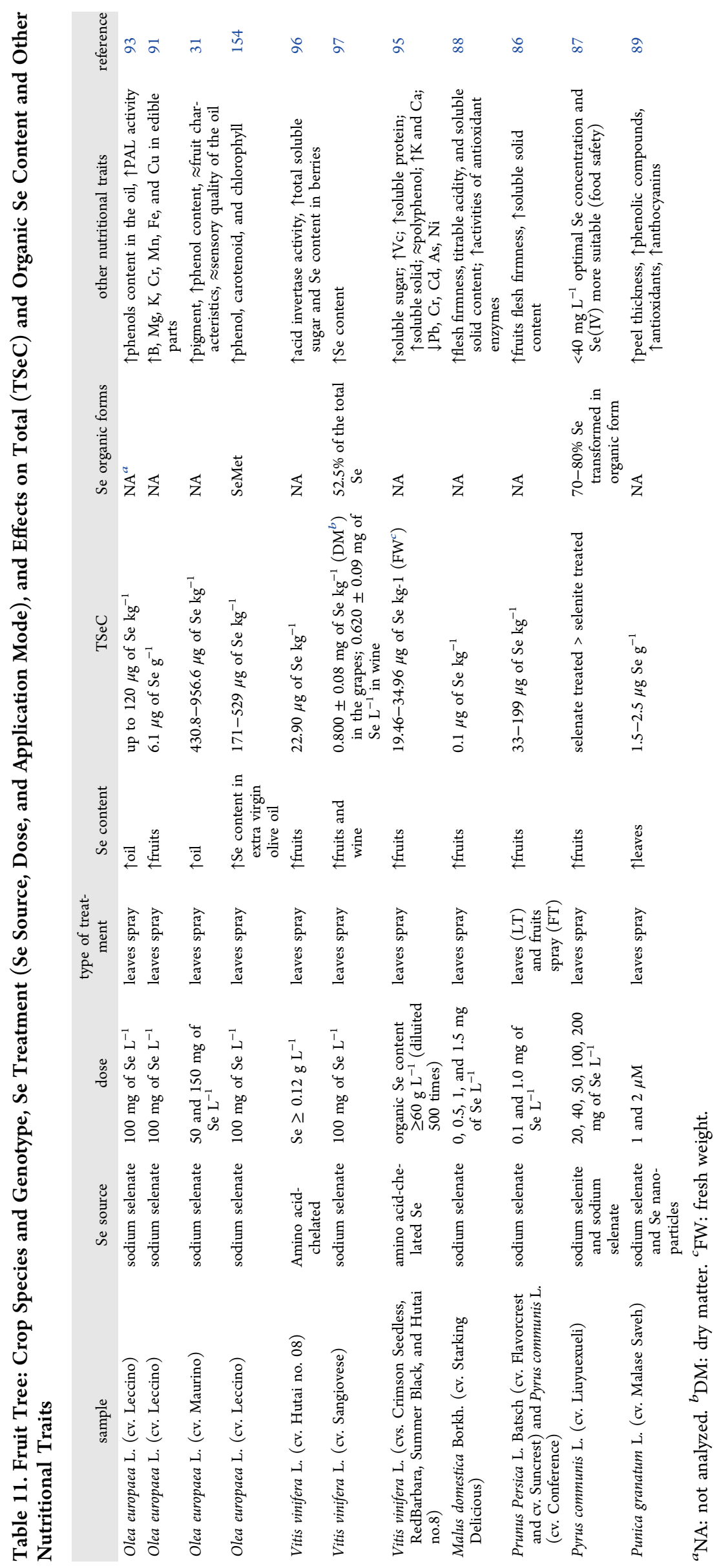


Table 12. Livestock (Species, Breed, and Muscle), Se Treatment (Se Dose and Source), and Main Effects of Se Supplementation in Animal Feeding

\begin{tabular}{|c|c|c|c|c|c|c|}
\hline species & breed & muscle & dose & Se source & main effects & reference \\
\hline \multicolumn{7}{|l|}{ Beef } \\
\hline & $\begin{array}{l}\text { Limousin } \times \\
\quad \text { Holstein-Friesian }\end{array}$ & $\begin{array}{l}\text { longissimus dorsi } \\
\text { and psoas major }\end{array}$ & $\begin{array}{l}0.30 \text { or }^{-1.50 ~} \mathrm{mg} \text { of } \\
\text { Se kg }\end{array}$ & $\begin{array}{l}\text { Se-enriched yeast, } \\
\text { sodium selenite }\end{array}$ & $\begin{array}{l}\uparrow S e \text { and GPx activity in meat, little or } \\
\text { no effect in meat oxidative stability }\end{array}$ & 155 \\
\hline & Charolais & $\begin{array}{l}\text { longissimus } \\
\text { thoracis }\end{array}$ & $0.3 \mathrm{mg}$ of $\mathrm{Se} \mathrm{kg}^{-1}$ & $\begin{array}{l}\text { Se-enriched yeast, } \\
\text { sodium selenite }\end{array}$ & $\begin{array}{l}\uparrow \text { Se concentrations for the Se yeast, } \\
\uparrow \text { color lightness, } \downarrow \text { shear force }\end{array}$ & 113 \\
\hline \multicolumn{7}{|l|}{ Pig } \\
\hline & $\begin{array}{l}{[\text { Landrace } \times \text { Yorkshire }]} \\
\times \text { Duroc }\end{array}$ & loin & $0.3 \mathrm{mg}$ of Se $\mathrm{kg}^{-1}$ & $\begin{array}{l}\text { Se-enriched yeast, } \\
\text { Se-proteinate }\end{array}$ & $\begin{array}{l}\downarrow \text { Se concentrations in loin for the Se } \\
\text { yeast }\end{array}$ & 156 \\
\hline & $\begin{array}{l}\text { Duroc } \times \text { Landrace } \\
\times \text { Yorkshire }\end{array}$ & longissimus dorsi & $0.3 \mathrm{mg} \mathrm{kg}^{-1}$ & Se-enriched yeast & $\begin{array}{l}\downarrow \text { drip loss; } \downarrow \text { lightness; =redness, } \\
\text { TBARS, and thiols }\end{array}$ & 157 \\
\hline \multicolumn{7}{|l|}{ Poultry } \\
\hline & broiler & breast and leg & $0.3 \mathrm{mg}$ of $\mathrm{Se} \mathrm{kg}^{-1}$ & sodium selenite & $\begin{array}{l}\uparrow \text { color degree, } \downarrow \text { drip losses, } \uparrow \text { serum } \\
\text { GPx }\end{array}$ & 158 \\
\hline & ArborAcres & pectoralis major & $\begin{array}{l}0.3,0.5,1.0 \text {, or } 2.0 \mathrm{mg} \\
\text { of Se } \mathrm{kg}^{-1}\end{array}$ & nano-Se & $\begin{array}{l}\downarrow T B A R S, \uparrow \text { muscle glutathione } \\
\text { peroxidase }\end{array}$ & 159 \\
\hline & Ross 308 & breast & $0.15 \mathrm{mg}$ of $\mathrm{Se} \mathrm{kg}^{-1}$ & SeMet & $\begin{array}{l}\uparrow \text { total antioxidant capacity, } \downarrow \text { malon } \\
\text { dialdehyde concentration }\end{array}$ & 160 \\
\hline & high line turkeys & $\begin{array}{l}\text { pectoralis major } \\
\text { and peroneus } \\
\text { longus }\end{array}$ & $\begin{array}{l}0.08 \text { or }^{-1} .23 \mathrm{mg} \text { of } \\
\text { Se kg }\end{array}$ & $\begin{array}{l}\text { seleno yeast, sodium } \\
\text { selenite }\end{array}$ & $\uparrow$ muscle tissue GPx activities & 161 \\
\hline \multicolumn{7}{|l|}{ Rabbit } \\
\hline & Californian & hindleg & $0.3 \mathrm{mg}$ of $\mathrm{Se} \mathrm{kg}^{-1}$ & SeMet & $\begin{array}{l}\uparrow \text { vitamin } \mathrm{E} \text { and Se; } \downarrow \text { index of lipid } \\
\text { oxidation, TBARS }\end{array}$ & 162 \\
\hline & New Zealand white & longissimus dorsi & $\begin{array}{l}10 \% \text { of Se-fortified olive } \\
\text { leaves }\left(2.10 \mathrm{mg} \mathrm{kg}^{-1}\right)\end{array}$ & $\begin{array}{l}\text { sodium selenate } \\
\text { solution }\end{array}$ & $\begin{array}{l}\uparrow \text { oleic acid, } \downarrow \text { desaturase index, } \\
\downarrow \text { TBARS }\end{array}$ & 117 \\
\hline & New Zealand white & longissimus dorsi & $\begin{array}{l}10 \% \text { of Se-fortified olive } \\
\text { leaves }\left(2.10 \mathrm{mg} \mathrm{kg}^{-1}\right)\end{array}$ & $\begin{array}{l}\text { sodium selenate } \\
\text { solution }\end{array}$ & $\begin{array}{l}\downarrow \text { TBARS, } \uparrow \text { GPx and } \alpha \text {-tocopherol, } \\
\uparrow \text { SeMet and SeCys }{ }_{2} \text { in meat }\end{array}$ & 114 \\
\hline & hyplus & loin and hindleg & $0.12 \mathrm{mg}$ of $\mathrm{Se} \mathrm{kg}^{-1}$ & $\begin{array}{l}\text { Se yeast (Sel-Plex, } \\
\text { Alltech) }\end{array}$ & $\uparrow$ Se content of meat & 100 \\
\hline \multicolumn{7}{|l|}{ Lamb } \\
\hline & Italian apennine lambs & longissimus dorsi & $0.30 \mathrm{mg}$ of Se $\mathrm{kg}^{-1}$ & sodium selenite & $\uparrow$ Se content of meat & 163 \\
\hline & lambs & longissimus dorsi & $0.30 \mathrm{mg}$ of $\mathrm{Se} \mathrm{kg}{ }^{-1}$ & $\begin{array}{l}\text { sodium selenite } \\
\quad+\text { Vit E }\end{array}$ & $\downarrow$ TBARS & 164 \\
\hline & $\begin{array}{l}\text { north country } \\
\text { mule } \times \text { Suffolk }\end{array}$ & longissimus dorsi & $\begin{array}{l}0,0.11,0.21 \text {, or } 0.31 \mathrm{mg} \\
\text { of Se } \mathrm{kg}^{-1}\end{array}$ & $\begin{array}{l}\text { selenized enriched } \\
\text { yeast, sodium } \\
\text { selenite }\end{array}$ & $\begin{array}{l}\text { no significant effects of treatment on } \\
\text { meat quality assessments }\end{array}$ & 165 \\
\hline
\end{tabular}

666 sources are used: inorganic (mainly selenite or selenate) and 667 organic, mainly in the form of SeMet (mainly as Se yeast or 668 SeMet preparations). Many factors can affect the activity and 669 efficacy of Se supplementation, such as the chemical form, 670 animal's health, and environmental conditions. Both organic 671 and inorganic forms are metabolized by animals, mainly as 672 SeCys, which is the form in which Se is also consumed by 673 humans (through animal-origin products). ${ }^{99}$ The body of 674 literature has reported that dietary Se supplementation 675 increases Se concentration in the meat of rabbits, ${ }^{100}$ 676 lambs, ${ }^{101}$ calves, $^{102}$ and chickens. ${ }^{103,104}$

677 Se is classified as an antioxidant microelement because it is a 678 part of the active center of the enzyme glutathione peroxidase $679(\mathrm{GPx})$ as well as a cofactor for thioredoxin reductase ${ }^{105}$ in 680 blood, liver, and edible tissues, ${ }^{106}$ which might be connected 681 with enhancing the immune response in mammals. There were 682 several documented reports that the addition of organic Se in 683 animal feed resulted in enhanced GPx activity and oxidative 684 stability of meat. ${ }^{107}$ Lipid oxidation is the main cause of 685 deteriorating meat quality in terms of color, flavor, texture, and 686 nutritional value. ${ }^{108}$ Joksimovic-Todorovic et al. ${ }^{109}$ reported 687 that Se has an effect of preserving the texture and sensory 688 characteristics of meat among domestic animals. Also, this type 689 of supplementation induced a decrease in the fat and 690 cholesterol contents in the meat (i.e., beef). ${ }^{110,111}$

691 Furthermore, Se may play a role in the alteration of lipid 692 metabolism; a decrease of the content of cholesterol in meat when adding Se would be a beneficial effect of its 693 supplementation. Nevertheless, the results concerning lipid 694 decrease $^{111}$ were not consistent with those reported in other 695 studies in cattle, ${ }^{112,113}$ rabbit, ${ }^{100,114}$ or pigs, ${ }^{115,116}$ for which no 696 difference was observed in lipid amount when adding Se. The 697 Se source was reported to have no direct effect on the meat 698 fatty acid profile; however, improving the oxidative stability of 699 meat indirectly affected the lipid composition, thereby 700 preserving the meat quality (Table 12). ${ }^{101,114,117}$ Such a 701 t12 discrepancy is mainly due to the form in which Se was 702 administered; the organic Se is known to be linked to a higher 703 Se content in the meat compared to the inorganic Se. ${ }^{118} 704$ However, SeMet, being incorporated into general proteins 705 (methionine codon), results in greater availability than SeCys, 706 demonstrating that it is easier to enrich meat with Se by 707 providing animals with additional SeMet in their feed. ${ }^{119} 708$

\section{PERSPECTIVES FOR FUTURE RESEARCH} 709

To date, scientific research has aimed to identify the Se effects 710 on the agronomic and physiological parameters of biofortified 711 plants, so most of the literature reviewed here considered very 712 high Se doses, which normally depress plant growth. This 713 approach, however, is often incompatible with the aim of 714 obtaining a Se-enriched food suitable for human and animal 715 diet. Therefore, when the production of Se-enriched foods that 716 provide nutritional benefits is the main goal of the research, it 717 
718 is necessary to carefully evaluate the applied Se-biofortification 719 strategies and cost-effective parameters. In this regard, the 720 challenge for future research on plant-food biofortification will 721 be to fine-tune the fortification techniques in terms of the Se 722 source and dose as well as the timing and modality of 723 application, tailored for each plant species, growth stage, and 724 cultivation condition. An abundance of the literature reviewed 725 here considered Se hyperaccumulator plants and very high Se 726 doses, which normally depress plant growth. Future research 727 should focus on biofortification at lower Se doses, since this is 728 expected to increase Se yield (i.e., the product between plant 729 biomass and its Se concentration), and with organic rather 730 than inorganic Se forms, while avoiding overabundant 731 accumulation in plant foods, thus limiting the risk of exceeding 732 the recommended dietary intake in humans. Finally, future 733 research on the Se biofortification of plants will have to 734 consider species that are scarcely exploited for food items but 735 may be of interest in food supplementation and nutraceutics. 736 An example is given by the Se enrichment of Pueraria lobata, 737 whose roots were found to be high in Se-containing proteins 738 and polysaccharides potentially useful as anticarcinogenic 739 molecules. $^{120}$

$740 \square$ AUTHOR INFORMATION

741 Corresponding Author

742 Paolo Benincasa - Department of Agricultural, Food and

743 Environmental Sciences, University of Perugia, Perugia 06123,

744 Italy; (i) orcid.org/0000-0001-8502-8026;

$745 \quad$ Email: paolo.benincasa@unipg.it

\section{Authors}

747 Roberto D'Amato - Department of Agricultural, Food and

748 Environmental Sciences, University of Perugia, Perugia 06123,

749 Italy; (i) orcid.org/0000-0003-3062-1417

750 Luca Regni - Department of Agricultural, Food and

751 Environmental Sciences, University of Perugia, Perugia 06123,

752 Italy

753 Beatrice Falcinelli - Department of Agricultural, Food and

754 Environmental Sciences, University of Perugia, Perugia 06123,

755 Italy; 10 orcid.org/0000-0002-9905-8178

756 Simona Mattioli - Department of Agricultural, Food and

757 Environmental Sciences, University of Perugia, Perugia 06123,

758 Italy; 이이이.org/0000-0001-5063-6785

759 Alessandro Dal Bosco - Department of Agricultural, Food and

760 Environmental Sciences, University of Perugia, Perugia 06123, Italy

Pablo Pacheco - Instituto de Quimica de San Luis, INQUISAL, Centro Cientifico-Tecnológico de San Luis (CCT-San Luis), Consejo Nacional de Investigaciones Científicas - Universidad Nacional de San Luis, Ciudad de San Luis 5700, Argentina

Primo Proietti - Department of Agricultural, Food and Environmental Sciences, University of Perugia, Perugia 06123, Italy

Elisabetta Troni - Department of Agricultural, Food and Environmental Sciences, University of Perugia, Perugia 06123, Italy

Claudio Santi - Department of Pharmaceutical Sciences, University of Perugia, Perugia 06123, Italy

Daniela Businelli - Department of Agricultural, Food and Environmental Sciences, University of Perugia, Perugia 06123, Italy

777 Complete contact information is available at:

778 https://pubs.acs.org/10.1021/acs.jafc.0c00172

\section{Notes}

The authors declare no competing financial interest.

\section{ACKNOWLEDGMENTS}

This manuscript is part of the scientific collaboration 782 untertaken under the umbrella of the international scientific 783 network SeSRedCat (Selenium Sulfur and Redox Catalysis). 784

\section{REFERENCES}

785

(1) Schwarz, K.; Foltz, C. M. Selenium as an Integral Part of Factor 786 3 Against Dietary Necrotic Liver Degeneration. J. Am. Chem. Soc. 787 1957, 79 (12), 3292-3293.

788

(2) Germ, M.; Stibilj, V. Selenium and plants. Acta Agric. Slov. 2007, 789 89 (1), 1 .

(3) Kuznetsov, V.; Kuznetsov, V. Selenium regulates the water status 791 of plants exposed to drought. Dokl. Biol. Sci. 2003, 390 (1/6), 266- 792 268.

(4) Xue, T.; Hartikainen, H.; Piironen, V. Antioxidative and growth- 794 promoting effect of selenium on senescing lettuce. Plant and Soil 795 2001, 237, 55-61.

796

(5) Pennanen, A.; Xue, T.; Hartikainen, H. Protective role of 797 selenium in plant subjected to severe UV irradiation stress. J. Appl. 798 Bot. 2002, 76 (1-2), 66-76.

799

(6) Schweizer, U.; Fradejas-Villar, N. Why 21? The significance of 800 selenoproteins for human health revealed by inborn errors of 801 metabolism. FASEB J. 2016, 30 (11), 3669-3681.

(7) Labunskyy, V. M.; Hatfield, D. L.; Gladyshev, V. N. 803 Selenoproteins: Molecular Pathways and Physiological Roles. Physiol. 804 Rev. 2014, 94 (3), 739-777.

(8) Lenardão, E. J.; Sancineto, L.; Santi, C. New frontiers in 806 organoselenium compounds; Springer International Publishing: Cham, 807 Switzerland, 2018.

(9) Steinbrenner, H.; Speckmann, B.; Klotz, L.-O. Selenoproteins: 809 Antioxidant selenoenzymes and beyond. Arch. Biochem. Biophys. 2016, 810 595, 113-119.

811

(10) Chun, O. K.; Floegel, A.; Chung, S.-J.; Chung, C. E.; Song, W. 812 O.; Koo, S. I. Estimation of Antioxidant Intakes from Diet and 813 Supplements in U.S. Adults. J. Nutr. 2010, 140 (2), 317-324. 814

(11) Kipp, A. P.; Strohm, D.; Brigelius-Flohé, R.; Schomburg, L.; 815 Bechthold, A.; Leschik-Bonnet, E.; Heseker, H. German Nutrition 816 Society (DGE). Revised reference values for selenium intake. J. Trace 817 Elem. Med. Biol. 2015, 32, 195-199.

818

(12) Neumeister, B.; Böhm, B. O. Klinikleitfaden Labordiagnostik; 819 Neumeister, B., Ravensburg, Böhm, B. O., Singapur, L. und, Eds.; 820 Munich, Germany, 2018.

(13) Rayman, M. P. Selenium intake, status, and health: a complex 822 relationship. Hormones 2019, 19 (1), 9-14.

(14) Lu, C. W.; Chang, H. H.; Yang, K. C.; Kuo, C. S.; Lee, L. T.; 824 Huang, K. C. High serum selenium levels are associated with 825 increased risk for diabetes mellitus independent of central obesity and 826 insulin resistance. BMJ. Open Diabetes Res. Care 2016, 4 (1), e000253. 827

(15) Achibat, H.; AlOmari, N. A.; Messina, F.; Sancineto, L.; 828 Khouili, M.; Santi, C. Organoselenium Compounds as Phytochem- 829 icals from the Natural Kingdom. Nat. Prod. Commun. 2015, 10 (11), 830 $1934578 X 1501001$.

831

(16) Barickman, T. C.; Kopsell, D. A.; Sams, C. E. Selenium 832 influences glucosinolate and isothiocyanates and increases sulfur 833 uptake in Arabidopsis thaliana and rapid-cycling Brassica oleracea. J. 834 Agric. Food Chem. 2013, 61 (1), 202-209.

(17) Schiavon, M.; Dall'Acqua, S.; Mietto, A.; Pilon-Smits, E. A. H.; 836 Sambo, P.; Masi, A.; Malagoli, M. Selenium fertilization alters the 837 chemical composition and antioxidant constituents of tomato 838 (Solanum lycopersicon L.). J. Agric. Food Chem. 2013, 61 (44), 839 $10542-10554$.

(18) D’Amato, R.; De Feudis, M.; Guiducci, M.; Businelli, D. Zea 841 mays L. Grain: Increase in Nutraceutical and Antioxidant Properties 842 Due to Se Fortification in Low and High Water Regimes. J. Agric. 843 Food Chem. 2019, 67 (25), 7050-7059. 
845 (19) Mao, G.; Feng, W.; Xiao, H.; Zhao, T.; Li, F.; Zou, Y.; Ren, Y.; $846 \mathrm{Zhu}$, Y.; Yang, L.; Wu, X. Purification, characterization, and 847 antioxidant activities of selenium-containing proteins and polysac848 charides in royal sun mushroom, Agaricus brasiliensis (Higher 849 Basidiomycetes). Int. J. Med. Mushrooms 2014, 16 (5), 463-475.

850 (20) Shang, D.; Li, Y.; Wang, C.; Wang, X.; Yu, Z.; Fu, X. A novel 851 polysaccharide from Se-enriched Ganoderma lucidum induces 852 apoptosis of human breast cancer cells. Oncol. Rep. 2011, 25 (1), $853267-272$.

854 (21) Institute of Medicine (US) Panel on Dietary Antioxidants and 855 Related Compounds. Dietary Reference Intakes for Vitamin C, Vitamin 856 E, Selenium, and Carotenoids; National Academies Press: Washington, 857 D.C., 2000.

858 (22) Torres, S.; Gil, R.; Silva, M. F.; Pacheco, P. Determination of 859 seleno-amino acids bound to proteins in extra virgin olive oils. Food 860 Chem. 2016, 197 (PartA), 400-405.

861 (23) Lopez, R.; Escudero, L.; D’Amato, R.; Businelli, D.; Trabalza862 Marinucci, M.; Cerutti, S.; Pacheco, P. Optimisation of microwave863 assisted acid hydrolysis for the determination of seleno-amino acids 864 bound to proteins in powdered milk, lyophilized milk and infant 865 formula. J. Food Compos. Anal. 2019, 79, 128-133.

866 (24) El Mehdawi, A. F.; Lindblom, S. D.; Cappa, J. J.; Fakra, S. C.; 867 Pilon-Smits, E. A. H. Do selenium hyperaccumulators affect selenium 868 speciation in neighboring plants and soil? An X-Ray Microprobe 869 Analysis. Int. J. Phytorem. 2015, 17 (8), 753-765.

870 (25) Gajdosechova, Z.; Mester, Z.; Feldmann, J.; Krupp, E. M. The 871 role of selenium in mercury toxicity - Current analytical techniques 872 and future trends in analysis of selenium and mercury interactions in 873 biological matrices. TrAC, Trends Anal. Chem. 2018, 104, 95-109.

874 (26) Bierla, K.; Godin, S.; Lobinski, R.; Szpunar, J. Advances in 875 electrospray mass spectrometry for the selenium speciation: Focus on 876 Se-rich yeast. TrAC, Trends Anal. Chem. 2018, 104, 87-94.

877 (27) Klencsár, B.; Li, S.; Balcaen, L.; Vanhaecke, F. High878 performance liquid chromatography coupled to inductively coupled 879 plasma - Mass spectrometry (HPLC-ICP-MS) for quantitative 880 metabolite profiling of non-metal drugs. TrAC, Trends Anal. Chem. $8812018,104,118-134$.

882 (28) Eiche, E.; Nothstein, A. K.; Göttlicher, J.; Steininger, R.; 883 Dhillon, K. S.; Neumann, T. The behaviour of irrigation induced Se in 884 the groundwater-soil-plant system in Punjab, India. Environ. Sci. 885 Process. Impacts 2019, 21 (6), 957-969.

886 (29) Nothstein, A. K.; Eiche, E.; Riemann, M.; Nick, P.; Winkel, L. 887 H. E.; Göttlicher, J.; Steininger, R.; Brendel, R.; von Brasch, M.; 888 Konrad, G.; et al. Tracking Se Assimilation and Speciation through 889 the Rice Plant - Nutrient Competition, Toxicity and Distribution. 890 PLoS One 2016, 11 (4), e0152081.

891 (30) Poggi, V.; Arcioni, A.; Filippini, P.; Pifferi, P. G. Foliar 892 application of selenite and selenate to potato (Solanum tuberosum): 893 Effect of a ligand agent on selenium content of tubers. J. Agric. Food 894 Chem. 2000, 48 (10), 4749-4751.

895 (31) D’Amato, R.; Proietti, P.; Nasini, L.; Del Buono, D.; 896 Tedeschini, E.; Businelli, D. Increase in the selenium content of 897 extra virgin olive oil: quantitative and qualitative implications. Grasas 898 Aceites 2014, 65 (2), e025.

899 (32) Longchamp, M.; Angeli, N.; Castrec-Rouelle, M. Selenium 900 uptake in Zea mays supplied with selenate or selenite under 901 hydroponic conditions. Plant Soil 2013, 362 (1-2), 107-117.

902 (33) Hajiboland, R.; Amjad, L. The effects of selenate and sulphate 903 supply on the accumulation and volatilization of Se by cabbage, 904 kohlrabi and alfalfa plants grown hydroponically. Agric. Food Sci. 905 2008, 17 (2), 177-189.

906 (34) Zhang, H.; Zhao, Z.; Zhang, X.; Zhang, W.; Huang, L.; Zhang, 907 Z.; Yuan, L.; Liu, X. Effects of foliar application of selenate and 908 selenite at different growth stages on Selenium accumulation and 909 speciation in potato (Solanum tuberosum L.). Food Chem. 2019, 286, 910 550-556.

911 (35) Govasmark, E.; Singh, B. R.; MacLeod, J. A.; Grimmett, M. G. 912 Selenium concentration in spring wheat and leaching water as influenced by application times of selenium and nitrogen. J. Plant 913 Nutr. 2008, 31 (2), 193-203.

914

(36) Yin, H.; Qi, Z.; Li, M.; Ahammed, G. J.; Chu, X.; Zhou, J. 915 Selenium forms and methods of application differentially modulate 916 plant growth, photosynthesis, stress tolerance, selenium content and 917 speciation in Oryza sativa L. Ecotoxicol. Environ. Saf. 2019, 169, 911- 918 917.

919

(37) Huang, G.; Ding, C.; Yu, X.; Yang, Z.; Zhang, T.; Wang, X. 920 Characteristics of Time-Dependent Selenium Biofortification of Rice 921 (Oryza sativa L.). J. Agric. Food Chem. 2018, 66 (47), 12490-12497. 922

(38) Mahn, A. Modelling of the effect of selenium fertilization on 923 the content of bioactive compounds in broccoli heads. Food Chem. 924 2017, 233, 492-499.

(39) Lu, X.; He, Z.; Lin, Z.; Zhu, Y.; Yuan, L.; Liu, Y.; Yin, X. Effects 926 of Chinese cooking methods on the content and speciation of 927 selenium in selenium bio-fortified cereals and soybeans. Nutrients 928 2018, 10 (3), 317.

(40) Lei, B.; Bian, Z.-h.; Yang, Q.-c.; Wang, J.; Cheng, R.-f.; Li, K.; 930 Liu, W.-k.; Zhang, Y.; Fang, H.; Tong, Y.-x. The positive function of 931 selenium supplementation on reducing nitrate accumulation in 932 hydroponic lettuce (Lactuca sativa L.). J. Integr. Agric. 2018, 17 (4), 933 837-846.

(41) da Silva, E.; Cidade, M.; Heerdt, G.; Ribessi, R.; Morgon, N.; 935 Cadore, S. Effect of selenite and selenate application on mineral 936 composition of lettuce plants cultivated under hydroponic conditions: 937 Nutritional balance overview using a multifaceted study. J. Braz. 938 Chem. Soc. 2018, 29 (2), 371-379.

(42) Shalaby, T.; Bayoumi, Y.; Alshaal, T.; Elhawat, N.; Sztrik, A.; 940 El-Ramady, H. Selenium fortification induces growth, antioxidant 941 activity, yield and nutritional quality of lettuce in salt-affected soil 942 using foliar and soil applications. Plant Soil 2017, 421 (1-2), 245- 943 258.

(43) Hawrylak-Nowak, B. Comparative effects of selenite and 945 selenate on growth and selenium accumulation in lettuce plants under 946 hydroponic conditions. Plant Growth Regul. 2013, 70 (2), 149-157. 947 (44) Ramos, S. J.; Faquin, V.; Guilherme, L. R. G.; Castro, E. M.; 948 Ávila, F. W.; Carvalho, G. S.; Bastos, C. E. A.; Oliveira, C. Selenium 949 biofortification and antioxidant activity in lettuce plants fed with 950 selenate and selenite. Plant, Soil Environ. 2010, 56 (12), 584-588. 951

(45) Businelli, D.; D’Amato, R.; Onofri, A.; Tedeschini, E.; Tei, F. 952 Se-enrichment of cucumber (Cucumis sativus L.), lettuce (Lactuca 953 sativa L.) and tomato (Solanum lycopersicum L. Karst) through 954 fortification in pre-transplanting. Sci. Hortic. (Amsterdam, Neth.) 2015, 955 197, 697-704.

(46) Ríos, J. J.; Blasco, B.; Cervilla, L. M.; Rubio-Wilhelmi, M. M.; 957 Ruiz, J. M.; Romero, L. Regulation of sulphur assimilation in lettuce 958 plants in the presence of selenium. Plant Growth Regul. 2008, 56 (1), 959 $43-51$.

(47) Rios, J. J.; Blasco, B.; Rosales, M. A.; Sanchez-Rodriguez, E.; 961 Leyva, R.; Cervilla, L. M.; Romero, L.; Ruiz, J. M. Response of 962 nitrogen metabolism in lettuce plants subjected to different doses and 963 forms of selenium. J. Sci. Food Agric. 2010, 90 (11), 1914-1919. 964

(48) Sanmartín, C.; Garmendia, I.; Romano, B.; Díaz, M.; Palop, J. 965 A.; Goicoechea, N. Mycorrhizal inoculation affected growth, mineral 966 composition, proteins and sugars in lettuces biofortified with organic 967 or inorganic selenocompounds. Sci. Hortic. (Amsterdam, Neth.) 2014, 968 180, 40-51.

(49) Ríos, J. J.; Blasco, B.; Cervilla, L. M.; Rosales, M. A.; Sanchez- 970 Rodriguez, E.; Romero, L.; Ruiz, J. M. Production and detoxification 971 of $\mathrm{H}_{2} \mathrm{O} 2$ in lettuce plants exposed to selenium. Ann. Appl. Biol. 2009, 972 154 (1), 107-116.

(50) Ferrarese, M.; Sourestani, M.; Quattrini, E.; Schiavi, M.; 974 Ferrante, A. Biofortification of spinach plants applying selenium in the 975 nutrient solution of floating system. Veg. Crops Res. Bull. 2012, 76 (1), 976 $127-136$.

(51) Saffaryazdi, A.; Lahouti, M.; Ganjeali, A.; Bayat, H. Impact of 978 Selenium Supplementation on Growth and Selenium Accumulation 979 on Spinach (Spinacia oleracea L.) Plants. Not. Sci. Biol. 2012, 4 (4), 980 95-100. 
982 (52) Oraghi Ardebili, Z.; Oraghi Ardebili, N.; Jalili, S.; Safiallah, S. 983 The modified qualities of basil plants by selenium and/or ascorbic 984 acid. Turk. J. Bot. 2015, 39 (3), 401-407.

985 (53) Hawrylak-Nowak, B. Enhanced Selenium Content in Sweet 986 Basil (Ocimum Basilicum L.) by Foliar Fertilization. Veg. Crops Res. 987 Bull. 2008, 69 (1), 63-72.

988 (54) Puccinelli, M.; Malorgio, F.; Terry, L. A.; Tosetti, R.; Rosellini, 989 I.; Pezzarossa, B. Effect of selenium enrichment on metabolism of 990 tomato (Solanum lycopersicum) fruit during postharvest ripening. J. 991 Sci. Food Agric. 2019, 99 (5), 2463-2472.

992 (55) Mezeyová, I.; Hegedûsová, A.; Andrejiová, A.; Hegedûs, O.; 993 Golian, M. Phytomass and content of essential oils in Ocimum 994 basilicum after foliar treatment with selenium. J. Int. Sci. Publ. 2016, 4 995 (1), 19-27.

996 (56) Bañuelos, G. S.; Arroyo, I.; Pickering, I. J.; Yang, S. I.; Freeman, $997 \mathrm{~J}$. L. Selenium biofortification of broccoli and carrots grown in soil 998 amended with Se-enriched hyperaccumulator Stanleya pinnata. Food 999 Chem. 2015, 166, 603-608.

1000 (57) Sindelárová, K.; Száková, J.; Tremlová, J.; Mestek, O.; Praus, L.; 1001 Kaňa, A.; Najmanová, J.; Tlustoš, P. The response of broccoli 1002 (Brassica oleracea convar. italica) varieties on foliar application of 1003 selenium: uptake, translocation, and speciation. Food Addit. Contam., 1004 Part A 2015, 32 (12), 2027-2038.

1005 (58) Mechora, S.; Germ, M.; Stibilj, V. Selenium compounds in 1006 selenium-enriched cabbage. Pure Appl. Chem. 2012, 84 (2), 259-268. 1007 (59) Ramos, S. J.; Yuan, Y.; Faquin, V.; Guilherme, L. R. G.; Li, L. 1008 Evaluation of genotypic variation of broccoli (Brassica oleracea var. 1009 italic) in response to selenium treatment. J. Agric. Food Chem. 2011, 101059 (8), 3657-3665.

1011 (60) Mechora, Š.; Stibilj, V.; Radešček, T.; Gaberščik, A.; Germ, M. 1012 Impact of se (VI) fertilization on se concentration in different parts of 1013 red cabbage plants. J. Food, Agric. Environ. 2011, 9 (2), 357-361.

1014 (61) Cuderman, P.; Kreft, I.; Germ, M.; Kovačevič, M.; Stibilj, V. 1015 Selenium species in selenium-enriched and drought-exposed potatoes. 1016 J. Agric. Food Chem. 2008, 56 (19), 9114-9120.

1017 (62) Turakainen, M.; Hartikainen, H.; Seppänen, M. M. Effects of 1018 selenium treatments on potato (Solanum tuberosum L.) growth and 1019 concentrations of soluble sugars and starch. J. Agric. Food Chem. 2004, 102052 (17), 5378-5382.

1021 (63) de Oliveira, V. C.; Faquin, V.; Andrade, F. R.; Carneiro, J. P.; da 1022 Silva Júnior, E. C.; de Souza, K. R. D.; Pereira, J.; Guilherme, L. R. G. 1023 Physiological and Physicochemical Responses of Potato to Selenium 1024 Biofortification in Tropical Soil. Potato Res. 2019, 62 (3), 315-331. 1025 (64) Shafiq, M.; Qadir, A.; Ahmad, S. R. Biofortification: A 1026 sustainable agronomic strategy to increase selenium content and 1027 antioxidant activity in Garlic. Appl. Ecol. Environ. Res. 2019, 17 (2), 1028 1685-1704.

1029 (65) Golubkina, N.; Zamana, S.; Seredin, T.; Poluboyarinov, P.; 1030 Sokolov, S.; Baranova, H.; Krivenkov, L.; Pietrantonio, L.; Caruso, G. 1031 Effect of selenium biofortification and beneficial microorganism 1032 inoculation on yield, quality and antioxidant properties of shallot 1033 bulbs. Plants 2019, 8 (4), 102.

1034 (66) Kápolna, E.; Hillestrøm, P. R.; Laursen, K. H.; Husted, S.; 1035 Larsen, E. H. Effect of foliar application of selenium on its uptake and 1036 speciation in carrot. Food Chem. 2009, 115 (4), 1357-1363.

1037 (67) Zhu, Z.; Chen, Y.; Shi, G.; Zhang, X. Selenium delays tomato 1038 fruit ripening by inhibiting ethylene biosynthesis and enhancing the 1039 antioxidant defense system. Food Chem. 2017, 219, 179-184.

1040 (68) Pezzarossa, B.; Rosellini, I.; Borghesi, E.; Tonutti, P.; Malorgio, 1041 F. Effects of Se-enrichment on yield, fruit composition and ripening of 1042 tomato (Solanum lycopersicum) plants grown in hydroponics. Sci. 1043 Hortic. (Amsterdam, Neth.) 2014, 165, 106-110.

1044 (69) Arulselvi, N. D. P. I. Effect of selenium fortification on 1045 biochemical activities of tomato (Solanum Lycopersicum) plants. Indo 1046 Am. J. Pharm. Res. 2014, 4 (10), 3997-4005.

1047 (70) Castillo-Godina, R. G.; Foroughbakhch-Pournavab, R.; 1048 Benavides-Mendoza, A. Effect of Selenium on Elemental Concen1049 tration and Antioxidant Enzymatic Activity of Tomato Plants. J. Agric. 1050 Sci. Technol. 2016, 18 (1), 233-244.
(71) Daniel, N.; Subramaniyan, G.; Chinnannan, K.; Indra, A. P. 1051 Antioxidant profiling of selenium fortified tomato (solanum 1052 lycopersicum). Int. Res. J. Pharm. 2015, 6 (5), 299-304. 1053 (72) Andrejiová, A.; Hegedûsová, A.; Adamec, S.; Hegedûs, O.; 1054 Mezeyová, I. Increasing of selenium content and qualitative 1055 parameters in tomato (Lycopersicon esculentum Mill.) after its foliar 1056 application. Potravin. Slovak J. Food Sci. 2019, 13 (1), 351-358. 1057 (73) Lintschinger, J.; Fuchs, N.; Moser, J.; Kuehnelt, D.; Goessler, 1058 W. J. Agric. Food Chem. 2000, 48, 5362-5368.

1059

(74) Kyriacou, M. C.; Rouphael, Y.; Di Gioia, F.; Kyratzis, A.; Serio, 1060 F.; Renna, M.; De Pascale, S.; Santamaria, P. Micro-scale vegetable 1061 production and the rise of microgreens. Trends Food Sci. Technol. 1062 2016, 57, 103-115.

1063

(75) Di Gioia, F.; Renna, M.; Santamaria, P. Sprouts, Microgreens 1064 and "Baby Leaf" Vegetables. In Minimally Processed Refrigerated Fruits 1065 and Vegetables; Fatih, Y., Wiley, R. C., Eds.; Springer US: Boston, MA, 1066 2017; pp 403-432.

1067

(76) Benincasa, P.; Falcinelli, B.; Lutts, S.; Stagnari, F.; Galieni, A. 1068 Sprouted grains: A comprehensive review. Nutrients 2019, 11 (2), 1069 421.

1070

(77) D’Amato, R.; Fontanella, M. C.; Falcinelli, B.; Beone, G. M.; 1071 Bravi, E.; Marconi, O.; Benincasa, P.; Businelli, D. Selenium 1072 Biofortification in Rice (Oryza sativa L.) Sprouting: Effects on Se 1073 Yield and Nutritional Traits with Focus on Phenolic Acid Profile. J. 1074 Agric. Food Chem. 2018, 66 (16), 4082-4090.

1075

(78) Liu, K.; Chen, F.; Zhao, Y.; Gu, Z.; Yang, H. Selenium 1076 accumulation in protein fractions during germination of Se-enriched 1077 brown rice and molecular weights distribution of Se-containing 1078 proteins. Food Chem. 2011, 127 (4), 1526-1531.

1079

(79) Ávila, F. W.; Yang, Y.; Faquin, V.; Ramos, S. J.; Guilherme, L. 1080 R. G.; Thannhauser, T. W.; Li, L. Impact of selenium supply on Se- 1081 methylselenocysteine and glucosinolate accumulation in selenium- 1082 biofortified Brassica sprouts. Food Chem. 2014, 165, 578-586. 1083

(80) Piekarska, A.; Kołodziejski, D.; Pilipczuk, T.; Bodnar, M.; 1084 Konieczka, P.; Kusznierewicz, B.; Hanschen, F. S.; Schreiner, M.; 1085 Cyprys, J.; Groszewska, M.; et al. The influence of selenium addition 1086 during germination of Brassica seeds on health-promoting potential of 1087 sprouts. Int. J. Food Sci. Nutr. 2014, 65 (6), 692-702.

1088

(81) Tian, M.; Xu, X.; Liu, Y.; Xie, L.; Pan, S. Effect of Se treatment 1089 on glucosinolate metabolism and health-promoting compounds in the 1090 broccoli sprouts of three cultivars. Food Chem. 2016, 190, 374-380. 1091 (82) Thosaikham, W.; Jitmanee, K.; Sittipout, R.; Maneetong, S.; 1092 Chantiratikul, A.; Chantiratikul, P. Evaluation of selenium species in 1093 selenium-enriched pakchoi (Brassica chinensis Jusl var parachinensis 1094 (Bailey) Tsen \& Lee) using mixed ion-pair reversed phase HPLC- 1095 ICP-MS. Food Chem. 2014, 145, 736-742.

1096

(83) Funes-Collado, V.; Morell-Garcia, A.; Rubio, R.; López- 1097 Sánchez, J. F. Study of selenocompounds from selenium-enriched 1098 culture of edible sprouts. Food Chem. 2013, 141 (4), 3738-3743. 1099 (84) Puccinelli, M.; Malorgio, F.; Rosellini, I.; Pezzarossa, B. 1100 Production of selenium-biofortified microgreens from selenium- 1101 enriched seeds of basil. J. Sci. Food Agric. 2019, 99 (12), 5601-5605. 1102 (85) Tedeschini, E.; Proietti, P.; Timorato, V.; D’Amato, R.; Nasini, 1103 L.; Dei Buono, D.; Businelli, D.; Frenguelli, G. Selenium as stressor 1104 and antioxidant affects pollen performance in Olea europaea. Flora 1105 2015, 215, 16.

1106

(86) Pezzarossa, B.; Remorini, D.; Gentile, M. L.; Massai, R. Effects 1107 of foliar and fruit addition of sodium selenate on selenium 1108 accumulation and fruit quality. J. Sci. Food Agric. 2012, 92 (4), 1109 $781-786$.

1110

(87) Deng, X. F.; Zhao, Z. Q.; Han, Z. Y.; Huang, L. Q.; Lv, C. H.; 1111 Zhang, Z. H.; Zhang, H. Q.; Liu, X. W. Selenium uptake and fruit 1112 quality of pear (Pyrus communis L.) treated with foliar Se application. 1113 J. Plant Nutr. Soil Sci. 2019, 182, 637-646. 1114

(88) Babalar, M.; Mohebbi, S.; Zamani, Z.; Askari, M. A. Effect of 1115 foliar application with sodium selenate on selenium biofortification 1116 and fruit quality maintenance of 'Starking Delicious' apple during 1117 storage. J. Sci. Food Agric. 2019, 99 (11), 5149-5156. 
1119 (89) Zahedi, S. M.; Hosseini, M. S.; Daneshvar Hakimi Meybodi, N.; 1120 Teixeira da Silva, J. A. Foliar application of selenium and nano1121 selenium affects pomegranate (Punica granatum cv. Malase Saveh) 1122 fruit yield and quality. S. Afr. J. Bot. 2019, 124, 350-358.

1123 (90) Anjum, S. A.; Ashraf, U.; Tanveer, M.; Khan, I.; Hussain, S.; 1124 Shahzad, B.; Zohaib, A.; Abbas, F.; Saleem, M. F.; Ali, I.; Wang, L. C.; 1125 et al. Drought Induced Changes in Growth, Osmolyte Accumulation 1126 and Antioxidant Metabolism of Three Maize Hybrids. Front. Plant Sci. 1127 2017, 08, 69.

1128 (91) D’Amato, R.; Petrelli, M.; Proietti, P.; Onofri, A.; Regni, L.; 1129 Perugini, D.; Businelli, D. Determination of changes in the 1130 concentration and distribution of elements within olive drupes (cv. 1131 Leccino) from Se biofortified plants, using laser ablation inductively 1132 coupled plasma mass spectrometry. J. Sci. Food Agric. 2018, 98 (13), 1133 4971-4977.

1134 (92) European Commission. Reports of the Scientific Committee for 1135 Food: Nutrient and Energy Intakes for the European Community, 31st 1136 series; Commission of the European Communities: Luxembourg, 1137 1993; pp 1-255.

1138 (93) D’Amato, R.; Proietti, P.; Onofri, A.; Regni, L.; Esposto, S.; 1139 Servili, M.; Businelli, D.; Selvaggini, R. Biofortification (Se): Does it 1140 increase the content of phenolic compounds in virgin olive oil 1141 (VOO)? PLoS One 2017, 12 (4), e0176580.

1142 (94) D’Amato, R.; De Feudis, M.; Hasuoka, P. E.; Regni, L.; 1143 Pacheco, P. H.; Onofri, A.; Businelli, D.; Proietti, P. The selenium 1144 supplementation influences olive tree production and oil stability 1145 against oxidation and can alleviate the water deficiency effects. Front. 1146 Plant Sci. 2018, 9, 1-8.

1147 (95) Zhu, S.; Liang, Y.; Gao, D.; An, X.; Kong, F. Spraying foliar 1148 selenium fertilizer on quality of table grape (Vitis vinifera L.) from 1149 different source varieties. Sci. Hortic. (Amsterdam, Neth.) 2017, 218, 1150 87-94.

1151 (96) Zhu, S.; Liang, Y.; An, X.; Kong, F.; Gao, D.; Yin, H. Changes 1152 in sugar content and related enzyme activities in table grape (Vitis 1153 vinifera L.) in response to foliar selenium fertilizer. J. Sci. Food Agric. 1154 2017, 97 (12), 4094-4102.

1155 (97) Fontanella, M. C.; D’Amato, R.; Regni, L.; Proietti, P.; Beone, 1156 G. M.; Businelli, D. Selenium speciation profiles in biofortified 1157 sangiovese wine. J. Trace Elem. Med. Biol. 2017, 43, 87-92.

1158 (98) Mehdi, Y.; Dufrasne, I. Selenium in cattle: A review. Molecules 1159 2016, 21 (4), 545.

1160 (99) Pezzarossa, B.; Petruzzelli, G.; Petacco, F.; Malorgio, F.; Ferri, $1161 \mathrm{~T}$. Absorption of selenium by Lactuca sativa as affected by 1162 carboxymethylcellulose. Chemosphere 2007, 67 (2), 322-329.

1163 (100) Dokoupilová, A.; Marounek, M.; Skřivanová, V.; Bŕezina, P. 1164 Selenium content in tissues and meat quality in rabbits fed selenium 1165 yeast. Czech J. Anim. Sci. 2008, 52 (6), 165-169.

1166 (101) Liu, S. M.; Sun, H. X.; Jose, C.; Murray, A.; Sun, Z. H.; 1167 Briegel, J. R.; Jacob, R.; Tan, Z. L. Phenotypic blood glutathione 1168 concentration and selenium supplementation interactions on meat 1169 colour stability and fatty acid concentrations in Merino lambs. Meat 1170 Sci. 2011, 87 (2), 130-139.

1171 (102) Skřivanová, E.; Marounek, M.; De Smet, S.; Raes, K. Influence 1172 of dietary selenium and vitamin E on quality of veal. Meat Sci. 2007, 117376 (3), 495-500.

1174 (103) Wang, Y. B.; Xu, B. H. Effect of different selenium source 1175 (sodium selenite and selenium yeast) on broiler chickens. Anim. Feed 1176 Sci. Technol. 2008, 144 (3-4), 306-314.

1177 (104) Perić, L.; Milošević, N.; Žikić, D.; Kanački, Z.; Džinić, N.; 1178 Nollet, L.; Spring, P. Effect of selenium sources on performance and 1179 meat characteristics of broiler chickens. J. Appl. Poult. Res. 2009, 18 1180 (3), 403-409.

1181 (105) Navarro-Alarcón, M.; López-Martínez, M. C. Essentiality of 1182 selenium in the human body: Relationship with different diseases. Sci. 1183 Total Environ. 2000, 249 (1-3), 347-371.

1184 (106) Surai, P. F. Selenium in poultry nutrition 2. Reproduction, egg 1185 and meat quality and practical applications. World's Poult. Sci. J. 2002, 118658 (4), 431-450.
(107) Suchý, P.; Straková, E.; Herzig, I. Selenium in poultry 1187 nutrition: A review. Czech J. Anim. Sci. 2014, 59 (11), 495-503. 1188 (108) Falowo, A. B.; Fayemi, P. O.; Muchenje, V. Natural 1189 antioxidants against lipid-protein oxidative deterioration in meat and 1190 meat products: A review. Food Res. Int. 2014, 64, 171-181. 1191

(109) Joksimovic-Todorovic, M.; Davidovic, V.; Sretenovic, L. The 1192 effect of diet selenium supplement on meat quality. Biotechnol. Anim. 1193 Husb. Biotehnol. u Stoc. 2012, 28 (3), 553-561.

1194

(110) Netto, A. S.; Zanetti, M. A.; Claro, G. R. D.; de Melo, M. P.; 1195 Vilela, F. G.; Correa, L. B. Effects of copper and selenium 1196 supplementation on performance and lipid metabolism in confined 1197 brangus bulls. Asian-Australas. J. Anim. Sci. 2014, 27 (4), 488-494. 1198 (111) Mehdi, Y.; Clinquart, A.; Hornick, J. L.; Cabaraux, J. F.; 1199 Istasse, L.; Dufrasne, I. Meat composition and quality of young 1200 growing belgian blue bulls offered a fattening diet with selenium 1201 enriched cereals. Can. J. Anim. Sci. 2015, 95 (3), 465-473. 1202 (112) Taylor, J. B.; Marchello, M. J.; Finley, J. W.; Neville, T. L.; 1203 Combs, G. F.; Caton, J. S. Nutritive value and display-life attributes of 1204 selenium-enriched beef-muscle foods. J. Food Compos. Anal. 2008, 211205 (2), 183-186.

1206

(113) Cozzi, G.; Prevedello, P.; Stefani, A. L.; Piron, A.; Contiero, 1207 B.; Lante, A.; Gottardo, F.; Chevaux, E. Effect of dietary 1208 supplementation with different sources of selenium on growth 1209 response, selenium blood levels and meat quality of intensively 1210 finished Charolais young bulls. Animal 2011, 5 (10), 1531-1538. 1211 (114) Mattioli, S.; Dal Bosco, A.; Duarte, J. M. M.; D’Amato, R.; 1212 Castellini, C.; Beone, G. M.; Fontanella, M. C.; Beghelli, D.; Regni, L.; 1213 Businelli, D.; et al. Use of Selenium-enriched olive leaves in the feed 1214 of growing rabbits: Effect on oxidative status, mineral profile and 1215 Selenium speciation of Longissimus dorsi meat. J. Trace Elem. Med. 1216 Biol. 2019, 51, 98-105.

1217

(115) Zhan, X. A.; Wang, M.; Zhao, R. Q.; Li, W. F.; Xu, Z. R. 1218 Effects of different selenium source on selenium distribution, loin 1219 quality and antioxidant status in finishing pigs. Anim. Feed Sci. Technol. 1220 2007, 132 (3-4), 202-211.

1221

(116) Svoboda, M.; Saláková, A.; Fajt, Z.; Ficek, R.; Buchtová, H.; 1222 Drábek, J. Selenium from Se-enriched lactic acid bacteria as a new Se 1223 source for growing-finishing pigs. Polym. J. Vet. Sci. 2009, 12 (3), 1224 $355-361$.

1225

(117) Mattioli, S.; Machado Duarte, J. M.; Castellini, C.; D’Amato, 1226 R.; Regni, L.; Proietti, P.; Businelli, D.; Cotozzolo, E.; Rodrigues, M.; 1227 Dal Bosco, A. Use of olive leaves (whether or not fortified with 1228 sodium selenate) in rabbit feeding: Effect on performance, carcass and 1229 meat characteristics, and estimated indexes of fatty acid metabolism. 1230 Meat Sci. 2018, 143, 230-236.

1231

(118) Pereira, A. S. C.; Santos, M. V. d.; Aferri, G.; Corte, R. R. P. d. 1232 S.; Silva, S. d. L. e; Freitas Junior, J. E. d.; Leme, P. R.; Renno, F. P. 1233 Lipid and selenium sources on fatty acid composition of intramuscular 1234 fat and muscle selenium concentration of Nellore steers. Rev. Bras. 1235 Zootec. 2012, 41 (11), 2357-2363.

1236

(119) Kieliszek, M.; Błażejak, S. Selenium: Significance, and outlook 1237 for supplementation. Nutrition 2013, 29 (5), 713-718. 1238 (120) Zou, Y.; Zhao, T.; Mao, G.; Zhang, M.; Zheng, D.; Feng, W.; 1239 Wang, W.; Wu, X.; Yang, L. Isolation, purification and character- 1240 isation of selenium-containing polysaccharides and proteins in 1241 selenium-enriched Radix puerariae. J. Sci. Food Agric. 2014, 94 (2), 1242 349-358.

1243

(121) Chen, L.; Yang, F.; Xu, J.; Hu, Y.; Hu, Q.; Zhang, Y.; Pan, G. 1244 Determination of selenium concentration of rice in China and effect 1245 of fertilization of selenite and selenate on selenium content of rice. J. 1246 Agric. Food Chem. 2002, 50 (18), 5128-5130.

1247

(122) Ngigi, P. B.; Lachat, C.; Masinde, P. W.; Du Laing, G. 1248 Agronomic biofortification of maize and beans in Kenya through 1249 selenium fertilization. Environ. Geochem. Health 2019, 3 (I), 2577- 1250 2591.

1251

(123) Wang, J.; Wang, Z.; Mao, H.; Zhao, H.; Huang, D. Increasing 1252 Se concentration in maize grain with soil- or foliar-applied selenite on 1253 the Loess Plateau in China. F. Crop. Res. 2013, 150, 83-90. 1254 
1255 (124) Xia, Q.; Yang, Z. P.; Xue, N. W.; Dai, X. J.; Zhang, X.; Gao, Z. 1256 Q. Effect of foliar application of selenium on nutrient concentration 1257 and yield of colored grain wheat in China. Appl. Ecol. Environ. Res. 1258 2019, 17 (2), 2187-2202.

1259 (125) Lara, T. S.; Lessa, J. H. de L.; de Souza, K. R. D.; Corguinha, 1260 A. P. B.; Martins, F. A. D.; Lopes, G.; Guilherme, L. R. G. Selenium 1261 biofortification of wheat grain via foliar application and its effect on 1262 plant metabolism. J. Food Compos. Anal. 2019, 81, 10-18.

1263 (126) Galinha, C.; Sanchez-Martinez, M.; Pacheco, A. M. G.; Freitas, 1264 M. d. C.; Coutinho, J.; Macas, B.; Almeida, A. S.; Perez-Corona, M. 1265 T.; Madrid, Y.; Wolterbeek, H. T. Characterization of Selenium1266 Enriched Wheat by Agronomic Biofortification. J. Food Sci. Technol. 1267 2015, 52, 4236-4245.

1268 (127) Poblaciones, M. J.; Rodrigo, S.; Santamaría, O.; Chen, Y.; 1269 McGrath, S. P. Agronomic selenium biofortification in Triticum 1270 durum under Mediterranean conditions: From grain to cooked pasta. 1271 Food Chem. 2014, 146, 378-384.

1272 (128) Rodrigo, S.; Santamaría, O.; López-Bellido, F. J.; Poblaciones, 1273 M. J. Agronomic selenium biofortification of two-rowed barley under 1274 Mediterranean conditions. Plant, Soil Environ. 2013, 59 (3), 115-120. 1275 (129) Rahman, M. M.; Erskine, W.; Zaman, M. S.; Thavarajah, P.; 1276 Thavarajah, D.; Siddique, K. H. M. Selenium biofortification in lentil 1277 (Lens culinaris Medikus subsp. culinaris): Farmers' field survey and 1278 genotype $\times$ environment effect. Food Res. Int. 2013, 54 (2), 159612791604

1280 (130) Poblaciones, M. J.; Rodrigo, S.; Santamaria, O.; Chen, Y.; 1281 Mcgrath, S. P. Selenium accumulation and speciation in biofortified 1282 chickpea (Cicer arietinum L.) under Mediterranean conditions. J. Sci. 1283 Food Agric. 2014, 94 (6), 1101-1106.

1284 (131) Chan, Q.; Afton, S. E.; Caruso, J. A. Selenium speciation 1285 profiles in selenite-enriched soybean (Glycine Max) by HPLC1286 ICPMS and ESI-ITMS. Metallomics 2010, 2, 147-153.

1287 (132) Shalaby, T.; Bayoumi, Y.; Alshaal, T.; Elhawat, N.; Sztrik, A.; 1288 El-Ramady, H. Selenium fortification induces growth, antioxidant 1289 activity, yield and nutritional quality of lettuce in salt-affected soil 1290 using foliar and soil applications. Plant Soil 2017, 421 (1-2), 2451291258.

1292 (133) Sabatino, L.; Ntatsi, G.; Iapichino, G.; D’Anna, F.; De 1293 Pasquale, C. Effect of selenium enrichment and type of application on 1294 yield, functional quality and mineral composition of curly endive 1295 grown in a hydroponic system. Agronomy 2019, 9 (4), 207.

1296 (134) Stibilj, V.; Smrkolj, P.; Jaćimović, R.; Osvald, J. Selenium 1297 uptake and distribution in chicory (Cichorium intybus L.) grown in 1298 an aeroponic system. Acta Agric. Slov. 2011, 97 (3), 189-196.

1299 (135) Puccinelli, M.; Malorgio, F.; Maggini, R.; Rosellini, I.; 1300 Pezzarossa, B. Biofortification of Ocimum basilicum L. plants with 1301 selenium. Acta Hortic. 2019, No. 1242, 663-670.

1302 (136) Barátová, S.; Mezeyova, I.; Hegedusová, A.; Andrejiová, A. 1303 Impact of biofortification, variety and cutting on chosen qualitative 1304 characteristic of basil (Ocimum basilicum L.). Acta Fytotech. Zootech. 1305 2015, 18 (03), 71-75.

1306 (137) Schiavon, M.; Berto, C.; Malagoli, M.; Trentin, A.; Sambo, P.; 1307 Dall'Acqua, S.; Pilon-Smits, E. A. H. Selenium Biofortification in 1308 Radish Enhances Nutritional Quality via Accumulation of Methyl1309 Selenocysteine and Promotion of Transcripts and Metabolites Related 1310 to Glucosinolates, Phenolics, and Amino Acids. Front. Plant Sci. 2016, $13117,1371$.

1312 (138) Hsu, F. C.; Wirtz, M.; Heppel, S. C.; Bogs, J.; Krämer, U.; 1313 Khan, M. S.; Bub, A.; Hell, R.; Rausch, T. Generation of Se-fortified 1314 broccoli as functional food: Impact of Se fertilization on $S$ 1315 metabolism. Plant, Cell Environ. 2011, 34 (2), 192-207.

1316 (139) Ježek, P.; Hlušek, J.; Lošák, T.; Jůzl, M.; Elzner, P.; Kráčmar, 1317 S.; Buňka, F.; Martensson, A. Effect of foliar application of selenium 1318 on the content of se-lected amino acids in potato tubers (Solanum 1319 tuberosum L.). Plant, Soil Environ. 2011, 57 (7), 315-320.

1320 (140) Chomchan, R.; Siripongvutikorn, S.; Puttarak, P.; Rattanapon, 1321 R. Influence of selenium bio-fortification on nutritional compositions, 1322 bioactive compounds content and anti-oxidative properties of young ricegrass (Oryza sativa L.). Funct. Foods Health Dis. 2017, 7 (3), 195- 1323 209.

1324

(141) Frias, J.; Gulewicz, P.; Martínez-Villaluenga, C.; Pilarski, R.; 1325 Blazquez, E.; Jiménez, B.; Gulewicz, K.; Vidal-Valverde, C. Influence 1326 of germination with different selenium solutions on nutritional value 1327 and cytotoxicity of lupin seeds. J. Agric. Food Chem. 2009, 57 (4), 1328 $1319-1325$

1329

(142) Bachiega, P.; Salgado, J. M.; de Carvalho, J. E.; Ruiz, A. L. T.; 1330 Schwarz, K.; Tezotto, T.; Morzelle, M. C. Antioxidant and 1331 antiproliferative activities in different maturation stages of broccoli 1332 (Brassica oleracea Italica) biofortified with selenium. Food Chem. 1333 2016, 190, 771-776.

1334

(143) Guardado-Félix, D.; Serna-Saldivar, S. O.; Cuevas-Rodríguez, 1335 E. O.; Jacobo-Velázquez, D. A.; Gutiérrez-Uribe, J. A. Effect of sodium 1336 selenite on isoflavonoid contents and antioxidant capacity of chickpea 1337 (Cicer arietinum L.) sprouts. Food Chem. 2017, 226, 69-74. 1338 (144) Arscott, S.; Goldman, I. Biomass effects and selenium 1339 accumulation in sprouts of three vegetable species grown in 1340 selenium-enriched conditions. HortScience 2012, 47 (4), 497-502. 1341

(145) Tie, M.; Gao, Y.; Xue, Y.; Zhang, A.; Yao, Y.; Sun, J.; Xue, S. 1342 Determination of selenium species and analysis of methyl-seleno-l- 1343 cysteine in Se-enriched mung bean sprouts by HPLC-MS. Anal. 1344 Methods 2016, 8 (15), 3102-3108.

1345

(146) Barrientos Carvacho, H.; Pérez, C.; Zúñiga, G.; Mahn, A. 1346 Effect of methyl jasmonate, sodium selenate and chitosan as 1347 exogenous elicitors on the phenolic compounds profile of broccoli 1348 sprouts. J. Sci. Food Agric. 2014, 94 (12), 2555-2561. 1349

(147) Pasko, P.; Gdula-Argasinska, J.; Podporska-Carroll, J.; Quilty, 1350 B.; Wietecha-Posluszny, R.; Tyszka-Czochara, M.; Zagrodzki, P. 1351 Influence of selenium supplementation on fatty acids profile and 1352 biological activity of four edible amaranth sprouts as new kind of 1353 functional food. J. Food Sci. Technol. 2015, 52 (8), 4724-4736. 1354

(148) Cuderman, P.; Ožbolt, L.; Kreft, I.; Stibilj, V. Extraction of Se 1355 species in buckwheat sprouts grown from seeds soaked in various Se 1356 solutions. Food Chem. 2010, 123 (3), 941-948. 1357

(149) Moulick, D.; Ghosh, D.; Chandra Santra, S. Evaluation of 1358 effectiveness of seed priming with selenium in rice during germination 1359 under arsenic stress. Plant Physiol. Biochem. 2016, 109, 571-578. 1360

(150) Khaliq, A.; Aslam, F.; Matloob, A.; Hussain, S.; Geng, M.; 1361 Wahid, A.; Ur Rehman, H. Seed priming with selenium: 1362 Consequences for emergence, seedling growth, and biochemical 1363 attributes of rice. Biol. Trace Elem. Res. 2015, 166 (2), 236-244. 1364 (151) Hussain, S.; Yin, H.; Peng, S.; Khan, F. A.; Khan, F.; 1365 Sameeullah, M.; Hussain, H. A.; Huang, J.; Cui, K.; Nie, L. 1366 Comparative transcriptional profiling of primed and non-primed 1367 rice seedlings under submergence stress. Front. Plant Sci. 2016, 7, 1- 1368 16.

1369

(152) Hussain, S.; Khan, F.; Cao, W.; Wu, L.; Geng, M. Seed 1370 Priming Alters the Production and Detoxification of Reactive Oxygen 1371 Intermediates in Rice Seedlings Grown under Sub-optimal Temper- 1372 ature and Nutrient Supply. Front. Plant Sci. 2016, 7, 439.

(153) Nawaz, F.; Ashraf, M. Y.; Ahmad, R.; Waraich, E. A. Selenium 1374 (Se) Seed Priming Induced Growth and Biochemical Changes in 1375 Wheat Under Water Deficit Conditions. Biol. Trace Elem. Res. 2013, 1376 151 (2), 284-293.

1377

(154) D’Amato, R.; De Feudis, M.; Hasuoka, P. E.; Regni, L.; 1378 Pacheco, P. H.; Onofri, A.; Businelli, D.; Proietti, P. The Selenium 1379 Supplementation Influences Olive Tree Production and Oil Stability 1380 Against Oxidation and Can Alleviate the Water Deficiency Effects. 1381 Front. Plant Sci. 2018, 9, 1-8.

1382

(155) Juniper, D. T.; Phipps, R. H.; Ramos-Morales, E.; Bertin, G. 1383 Effect of dietary supplementation with selenium-enriched yeast or 1384 sodium selenite on selenium tissue distribution and meat quality in 1385 beef cattle. J. Anim. Sci. 2008, 86 (11), 3100-3109.

1386

(156) Qiu, Y.; Liu, Q.; Beta, T. Antioxidant properties of commercial 1387 wild rice and analysis of soluble and insoluble phenolic acids. Food 1388 Chem. 2010, 121 (1), 140-147.

1389

(157) Kim, M. Y.; Lee, S. H.; Jang, G. Y.; Li, M.; Lee, Y. R.; Lee, J.; 1390 Jeong, H. S. Changes of phenolic-acids and vitamin $\mathrm{E}$ profiles on 1391 
1392 germinated rough rice (Oryza sativa L.) treated by high hydrostatic 1393 pressure. Food Chem. 2017, 217, 106-111.

1394 (158) Yang, Y. R. Effect of organic and inorganic selenium 1395 supplementation on growth performance, meat quality and anti1396 oxidant property of broilers. Afr. J. Biotechnol. 2012, 11 (12), 303113973036.

1398 (159) Cai, S. J.; Wu, C. X.; Gong, L. M.; Song, T.; Wu, H.; Zhang, L. 1399 Y. Effects of nano-selenium on performance, meat quality, immune 1400 function, oxidation resistance, and tissue selenium content in broilers. 1401 Poult. Sci. 2012, 91 (10), 2532-2539.

1402 (160) Wang, Y.X.; Zhan, X.A.; Yong, D.; Zhang, X.W.; Wu, R.J. 1403 Effects of selenomethionine and sodium selenite supplementation on 1404 meat quality, selenium distribution and antioxidant status in broilers. 1405 Czech J. Anim. Sci. 2011, 56 (7), 305-313.

1406 (161) Juniper, D. T.; Phipps, R. H.; Bertin, G. Effect of dietary 1407 supplementation with selenium-enriched yeast or sodium selenite on 1408 selenium tissue distribution and meat quality in commercial-line 1409 turkeys. Animal 2011, 5 (11), 1751-1760.

1410 (162) Ebeid, T. A.; Zeweil, H. S.; Basyony, M. M.; Dosoky, W. M.; 1411 Badry, H. Fortification of rabbit diets with vitamin $\mathrm{E}$ or selenium 1412 affects growth performance, lipid peroxidation, oxidative status and 1413 immune response in growing rabbits. Livest. Sci. 2013, 155 (2-3), $1414323-331$.

1415 (163) Vignola, G.; Lambertini, L.; Mazzone, G.; Giammarco, M.; 1416 Tassinari, M.; Martelli, G.; Bertin, G. Effects of selenium source and 1417 level of supplementation on the performance and meat quality of 1418 lambs. Meat Sci. 2009, 81 (4), 678-685.

1419 (164) Ripoll, G.; Joy, M.; Muñoz, F. Use of dietary vitamin E and 1420 selenium ( $\mathrm{Se}$ ) to increase the shelf life of modified atmosphere 1421 packaged light lamb meat. Meat Sci. 2011, 87 (1), 88-93.

1422 (165) Juniper, D. T.; Phipps, R. H.; Ramos-Morales, E.; Bertin, G. 1423 Effects of dietary supplementation with selenium enriched yeast or 1424 sodium selenite on selenium tissue distribution and meat quality in 1425 lambs. Anim. Feed Sci. Technol. 2009, 149 (3-4), 228-239. 